Article

\title{
The $25 \mathrm{kDa} \mathrm{H}_{\mathrm{CN}}$ Domain of Clostridial Neurotoxins Is Indispensable for Their Neurotoxicity
}

\author{
Julian Deppe ${ }^{\dagger}$, Jasmin Weisemann ${ }^{\dagger}$, Stefan Mahrhold and Andreas Rummel *(D) \\ Institut für Toxikologie, Medizinische Hochschule Hannover, 30625 Hannover, Germany; \\ deppe.julian@mh-hannover.de (J.D.); weisemann.jasmin@mh-hannover.de (J.W.); \\ mahrhold.stefan@mh-hannover.de (S.M.) \\ * Correspondence: rummel.andreas@mh-hannover.de \\ † Equal contribution.
}

Received: 15 August 2020; Accepted: 20 November 2020; Published: 26 November 2020

\begin{abstract}
The extraordinarily potent clostridial neurotoxins (CNTs) comprise tetanus neurotoxin (TeNT) and the seven established botulinum neurotoxin serotypes (BoNT/A-G). They are composed of four structurally independent domains: the roles of the catalytically active light chain, the translocation domain $\mathrm{H}_{\mathrm{N}}$, and the $\mathrm{C}$-terminal receptor binding domain $\mathrm{H}_{\mathrm{CC}}$ are largely resolved, but that of the $\mathrm{H}_{\mathrm{CN}}$ domain sandwiched between $\mathrm{H}_{\mathrm{N}}$ and $\mathrm{H}_{\mathrm{CC}}$ has remained unclear. Here, mutants of BoNT/A, BoNT/B, and TeNT were generated by deleting their $\mathrm{H}_{\mathrm{CN}}$ domains or swapping $\mathrm{H}_{\mathrm{CN}}$ domains between each other. Both deletion and replacement of TeNT $\mathrm{H}_{\mathrm{CN}}$ domain by $\mathrm{H}_{\mathrm{CN}} \mathrm{A}$ and $\mathrm{H}_{\mathrm{CN}} \mathrm{B}$ reduced the biological activity similarly, by $\sim 95 \%$, whereas BoNT/A and B deletion mutants displayed $>500$-fold reduced activity in the mouse phrenic nerve hemidiaphragm assay. Swapping $\mathrm{H}_{\mathrm{CN}}$ domains between BoNT/A and B hardly impaired their biological activity, but substitution with $\mathrm{H}_{\mathrm{CN}} \mathrm{T}$ did. Binding assays revealed that in the absence of $\mathrm{H}_{\mathrm{CN}}$, not all receptor binding sites are equally well accessible. In conclusion, the presence of $\mathrm{H}_{\mathrm{CN}}$ is vital for CNTs to exert their neurotoxicity. Although structurally similar, the $\mathrm{H}_{\mathrm{CN}}$ domain of TeNT cannot equally substitute those of BoNT and vice versa, leaving the possibility that $\mathrm{H}_{\mathrm{CN}} \mathrm{T}$ plays a different role in the intoxication mechanism of TeNT.
\end{abstract}

Keywords: botulinum neurotoxin; BoNT/A; BoNT/B; tetanus neurotoxin; $\mathrm{H}_{\mathrm{CN}}$ domain; synaptic vesicle protein; gangliosides

Key Contribution: Deletion of the $25 \mathrm{kDa} \mathrm{H}_{\mathrm{CN}}$ domain of tetanus and botulinum neurotoxin $\mathrm{A}$ and $\mathrm{B}$ massively impairs their neurotoxicity, but $\mathrm{H}_{\mathrm{CN}}$ of $\mathrm{BoNT} / \mathrm{A}$ and $\mathrm{B}$ are interchangeable.

\section{Introduction}

The family of clostridial neurotoxins (CNTs) consists of tetanus neurotoxin (TeNT), the seven established botulinum neurotoxin serotypes (BoNT/A-G), and the recently identified novel types BoNT/HA (aka H \& FA), BoNT/X, and eBoNT/J (aka BoNT/En) from Enterococcus [1-4]. Lately, the insecticidal neurotoxin PMP1 isolated from a Paraclostridium bifermentans strain has also been identified as a structural homologue of CNTs [5]. Historically, botulinum neurotoxins (BoNTs) are produced by the bacteria Clostridium botulinum and are the most poisonous protein toxins known [6]. They cause the disease botulism by blocking release of acetylcholine at the neuromuscular junction, resulting in muscle relaxation. Therefore, BoNTs are extensively used in medical and cosmetic applications [7]. TeNT is similarly toxic, but blocks the release of glycine and GABA at inhibitory neurons, resulting in spastic paralysis and the disease tetanus. 
CNTs are AB-protein toxins of $150 \mathrm{kDa}$ molecular weight (MW), which comprise a $50 \mathrm{kDa}$ light chain (LC) linked by a disulfide bridge to the heavy chain (HC), the latter being divided into three independent domains: $\mathrm{H}_{\mathrm{N}}(50 \mathrm{kDa}$ N-terminal half of $\mathrm{HC}), \mathrm{H}_{\mathrm{CN}}$, and $\mathrm{H}_{\mathrm{CC}}(25 \mathrm{kDa}$ each) (Figure 1) [8-11]. $\mathrm{H}_{\mathrm{CN}}$ and $\mathrm{H}_{\mathrm{CC}}$ together form the $50 \mathrm{kDa} \mathrm{H}_{\mathrm{C}}$ fragment, which is a well expressed, soluble, non-toxic protein used for example as a vaccine [12]. LC, $\mathrm{H}_{\mathrm{N}}$, and $\mathrm{H}_{\mathrm{C}}$ perform individual tasks in the intoxication process: The $\mathrm{N}$-terminal $\mathrm{LC}$ is a $\mathrm{Zn}^{2+}$-dependent metalloprotease, $\mathrm{H}_{\mathrm{N}}$ is the translocation domain, and the $\mathrm{C}$-terminal $\mathrm{H}_{\mathrm{C}}$ fragment is the receptor binding domain [13]. Extensive analyses of the interaction between neuronal receptors and CNT has revealed so far that, with one exception, all receptor binding sites are located within the C-terminal $25 \mathrm{kDa} \mathrm{H} \mathrm{H}_{\mathrm{CC}}$ domain of $\mathrm{H}_{\mathrm{C}}$ [14]. Only the $\mathrm{H}_{\mathrm{CN}}$ of BoNT/A harbors part of the $\mathrm{N}$-glycan binding site of its protein receptor SV2 [15,16]. Accordingly, a mutant form of recombinant BoNT/A lacking $\mathrm{H}_{\mathrm{CN}}\left(\mathrm{rA} \Delta \mathrm{H}_{\mathrm{CN}}\right)$ showed a 33,000-fold reduced lethality compared to wild-type BoNT/A, presumably due to impaired SV2C binding [17]. However, any additional function of $\mathrm{H}_{\mathrm{CN}} \mathrm{A}$ and the role of the $25 \mathrm{kDa} \mathrm{H}_{\mathrm{CN}}$ domain in all other serotypes still remains elusive.
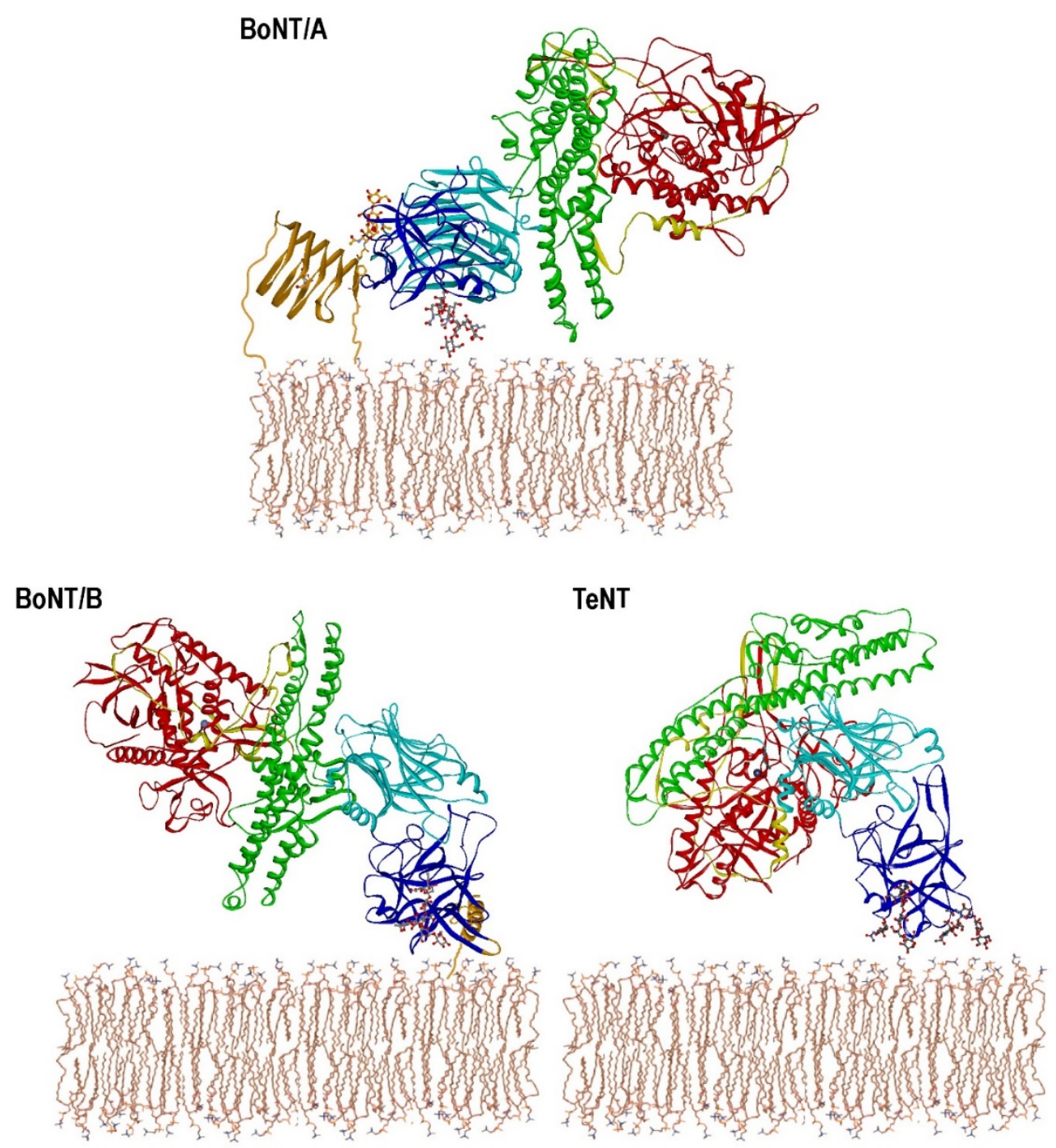

Figure 1. Membrane approach models of crystal structures of BoNT/A, BoNT/B, and TeNT in complex with the luminal parts of their neuronal receptor molecules glycosylated SV2C, Syt-II (orange ribbons) and complex polysialo-gangliosides (balls and sticks). Red ribbons, $50 \mathrm{kDa}$ light chain (LC); yellow ribbons, belt wrapping around the LC; green ribbons, translocation domain $\left(\mathrm{H}_{\mathrm{N}}\right)$; light blue ribbon, $\mathrm{N}$-terminal half of $\mathrm{H}_{\mathrm{C}}$ fragment $\left(\mathrm{H}_{\mathrm{CN}}\right)$; dark blue ribbon, $\mathrm{C}$-terminal half of $\mathrm{H}_{\mathrm{C}}$ fragment $\left(\mathrm{H}_{\mathrm{CC}}\right)$. 
The BoNT molecular mechanism of action at the cholinergic neuron starts with a low affinity binding of the $\mathrm{H}_{\mathrm{CC}}$ domain to complex polysialo-gangliosides and subsequent high affinity binding to different synaptic vesicle (SV) protein receptors [14]. In variance, TeNT interacts with extracellular matrix proteins nidogen-1 and 2 first [18], although it remains unclear how this interaction triggers membrane approach of TeNT. In proximity of the plasma membrane TeNT binds to one or two molecules of complex polysialo-gangliosides, a second ganglioside would displace nidogen from its sialic acid binding site. Unlike BoNTs, TeNT is then sorted into vesicles of neutral $\mathrm{pH}$ lumen and undergoes retrograde axonal transport to reach the inhibitory neuron. BoNTs undergo receptor-mediated endocytosis via synaptic vesicles. Upon acidification of lumen, the BoNTs change their conformation and presumably insert a pore or channel into the vesicle membrane [19]. The partially unfolded LC is translocated through the pore formed by the $\mathrm{H}_{\mathrm{N}}$ domain into the neuronal cytosol and is released after reduction of the disulfide bridge connecting LC and HC by thioredoxin and its reductase [19-21]. Here, the hydrolysis of a specific soluble $N$-ethylmaleimide-sensitive factor attachment protein receptor (SNARE) protein takes place; in the case of BoNT/A synaptosome-associated protein of $25 \mathrm{kDa}$ (SNAP-25) is specifically cleaved at Q197-R198 [22,23], while BoNT/B and TeNT cleave the identical peptide bond Q76-F77 in synaptobrevin/VAMP-2 [24]. This cleavage results in inhibition of the neurotransmitter release into the synaptic cleft, leading to flaccid and in the case of TeNT to spastic paralysis, respectively, and eventually to death by respiratory failure.

BoNT/A, B, E, F, and G and TeNT all possess a single ganglioside binding site (GBS) comprising a conserved motif [25-27], which specifically recognizes complex polysialo-gangliosides albeit with submicromolar affinity [28-31]. In addition to this conserved GBS, TeNT comprises a second ganglioside binding site interacting with sialic acids as well as defined peptide motifs found, e.g., in nidogen- 1 and 2 [18,32-34]. The SV proteins synaptotagmin-I and -II (Syt-I/-II) serve as protein receptors for BoNT/B, G, and the mosaic type BoNT/DC [35-41], whereas the three isoforms of the synaptic vesicle glycoprotein 2 (SV2A-C) were identified as protein receptors for BoNT/A [42,43]. Furthermore, glycosylated SV2A and B exclusively serve as protein receptors for BoNT/E [44]. Only the luminal domain 4 (LD4) connecting TMD 7 and 8 of all three SV2 isoforms interacts with BoNT/A $\mathrm{H}_{\mathrm{C}}[42,43]$ and folds into a right-handed, quadrilateral $\beta$-helix (Figure 1), which binds to BoNT/A next to the interface of $\mathrm{H}_{\mathrm{CN}}$ and $\mathrm{H}_{\mathrm{CC}}[15,45,46]$. An N-glycan conserved in SV2A-C increases the affinity of BoNT/A to SV2C 12-fold by binding with its glycan core into a cleft between the $\mathrm{H}_{\mathrm{CN}}$ and $\mathrm{H}_{\mathrm{CC}}$ domains [16,47]. This SV2C-binding site locates almost opposite to the GBS in $\mathrm{H}_{\mathrm{CC}} \mathrm{A}$ with a distance of approximately $40 \AA$. In contrast, the Syt binding site locates at the tip of the BoNT/B, G, and DC $\mathrm{H}_{\mathrm{CC}}$ domains in close proximity to the single GBS [27,30,46,48,49].

The isolated $25 \mathrm{kDa}$ domains $\mathrm{H}_{\mathrm{CN}}$ and $\mathrm{H}_{\mathrm{CC}}$ of $\mathrm{BoNT} / \mathrm{A}, \mathrm{B}$, and $\mathrm{G}$ are readily produced, but only $\mathrm{H}_{\mathrm{CC}}$ of BoNT/B and G display binding to their protein receptors Syt-I/-II [39]. A fusion protein of enhanced green fluorescent protein (EGFP) and BoNT/A $H_{C N}\left(E G F P-H_{C N} / A\right)$ binds to the plasma membrane of the neuronally differentiated NSC-34 cells and to spinal cord motoneurons all along the cell surface in discrete spots identified as sphingomyelin-enriched membrane microdomains, but is not internalized [50]. Interestingly, EGFP- $\mathrm{H}_{\mathrm{CN}} / \mathrm{A}$ binds with a similar pattern also to the plasma membrane of the epithelial cell lines HeLa and Caco-2, but does not transcytose polarized T84 monolayers as $\mathrm{H}_{\mathrm{C}} \mathrm{A}$ does [51]. However, the epithelial binding could not be demonstrated for the entire receptor binding domain $\mathrm{H}_{\mathrm{C}} \mathrm{A}$ comprising $\mathrm{H}_{\mathrm{CN}}$ and $\mathrm{H}_{\mathrm{CC}}$ ("EGFP and EGFP- $\mathrm{H}_{\mathrm{C}} / \mathrm{A}$ did not bind to HeLa cells."; $\mathrm{L}$. Muraro PhD thesis, 2009, Figure 20, p. 56). In a dot-blot assay, EGFP-H $\mathrm{CNN}_{\mathrm{C}} / \mathrm{A}$ binds phosphatidylinositol phosphates (PI(5)P > PI(3)P > PI(4)P) [50].

In this study, we deleted or substituted the $\mathrm{H}_{\mathrm{CN}}$ domain within BoNT/A, BoNT/B, and TeNT holotoxins to obtain insight into its function. Corresponding crystal structures and biochemical data guided us to define the sequence comprising the $\mathrm{H}_{\mathrm{CN}}$ domains (Figures 1 and 2). At first, mutants of BoNT/A, BoNT/B, and TeNT were generated either lacking their $\mathrm{H}_{\mathrm{CN}}$ domains or containing $\mathrm{H}_{\mathrm{CN}}$ domains from one of the other two CNTs. Their residual biological activity was tested using the mouse phrenic nerve hemidiaphragm (MPN) assay. Pull-down assays with GST-fusion proteins of their SV 
protein receptors as well as with ganglioside incorporated liposomes verified the functionality of the binding areas and thereby correct folding of the $\mathrm{H}_{\mathrm{CC}}$ domains. Secondary structure analyses by circular dichroism spectroscopy (CD) of mutants confirmed these findings.

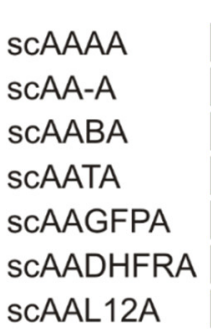

ScBBBB

SCBB-B

SCBBAB

scBBTB

scTTTT

SCTT-T

SCTTAT

ScTTBT
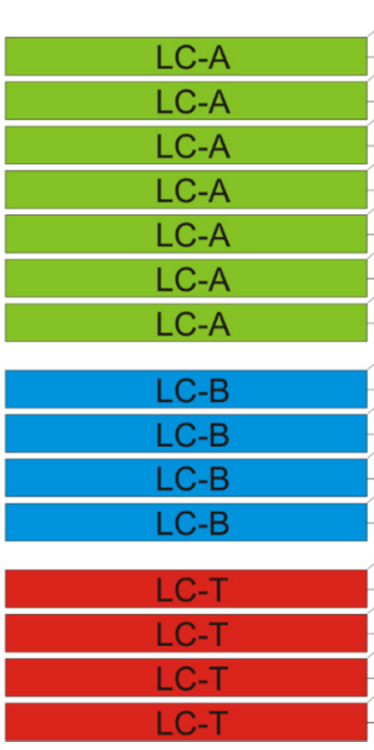
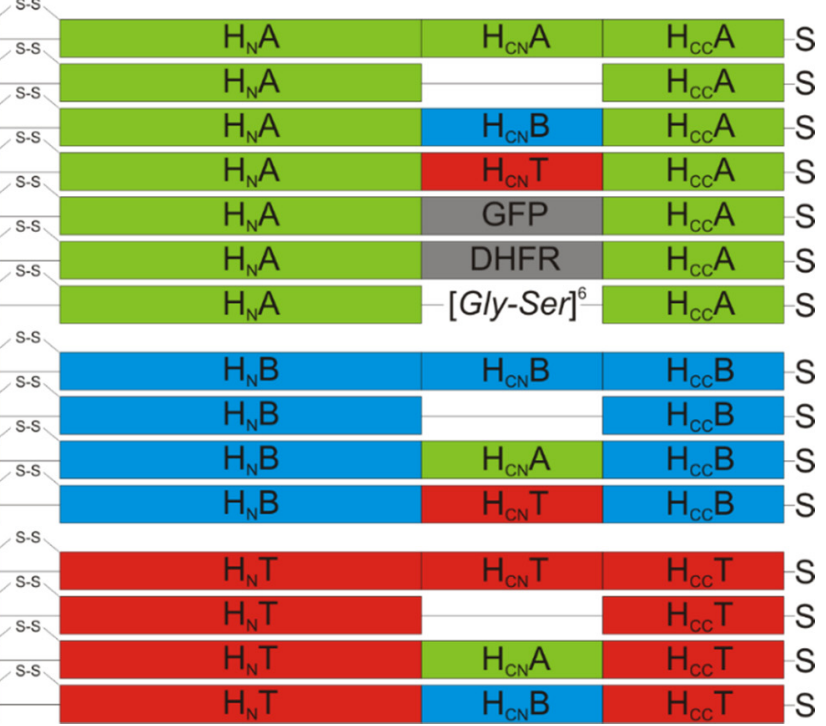

(A)

\begin{tabular}{|l|l|l|}
\hline & $\mathbf{H}_{\mathrm{CN}} \mathbf{A}$ & $\mathbf{H}_{\mathrm{CN}} \mathbf{B}$ \\
\hline $\mathbf{H}_{\mathrm{CN}} \mathbf{B}$ & 52.1 & \\
\hline $\mathbf{H}_{\mathrm{CN}} \mathbf{T}$ & 38.5 & 33.5 \\
\hline \multirow{2}{*}{} & \multicolumn{2}{|c|}{ [\% AA Identity] } \\
\cline { 2 - 2 }
\end{tabular}

(B)

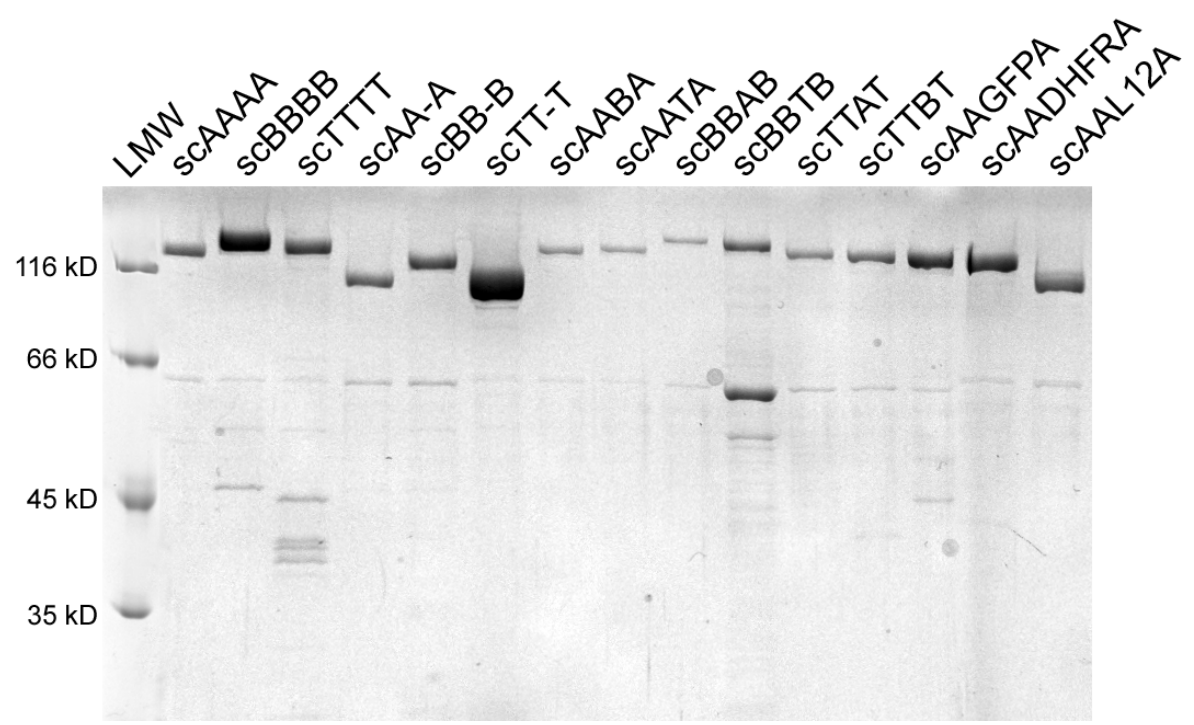

(C)

Figure 2. Cont. 


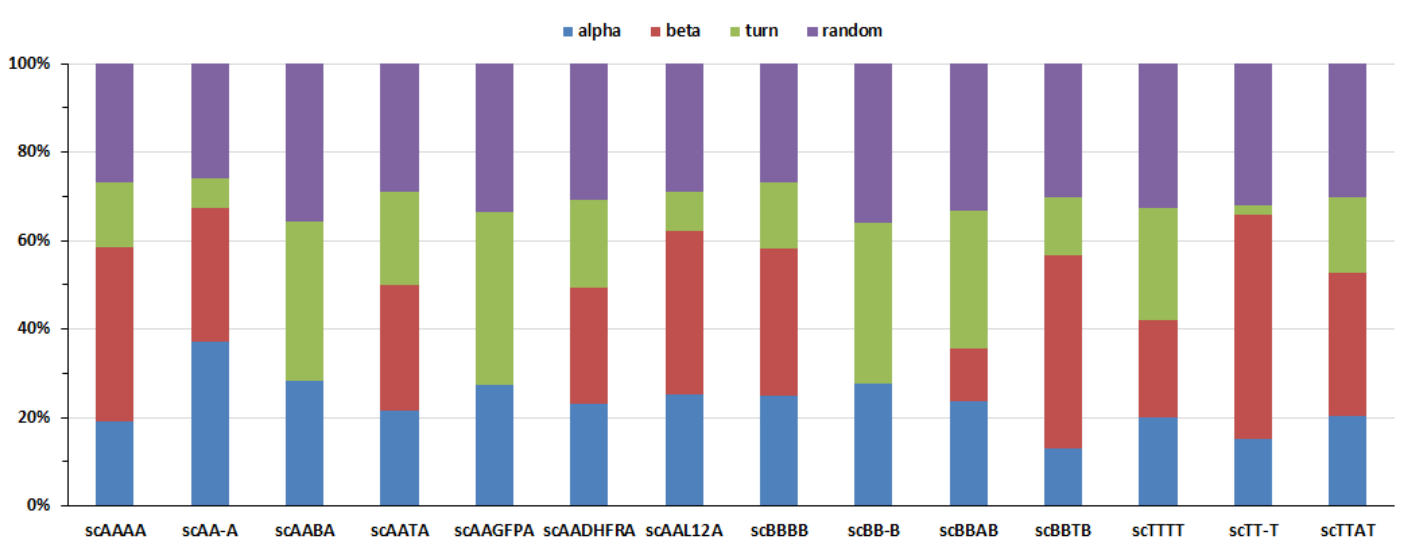

(D)

Figure 2. (A) Schematic overview of the generated BoNT/A, B, and TeNT deletion mutants and hybrids. scAA-A lack residues K871-N1093, scBB-B S858-Y1080, and scTT-T I880-I1111, respectively. GFP, green fluorescent protein; DHFR, dihydrofolate reductase; L12 = [GlySer $]_{6}$-linker; sc single chain. A capital letter according to the serotype origin was assigned to each of the four domains $\left(\mathrm{LC}, \mathrm{H}_{\mathrm{N}}, \mathrm{H}_{\mathrm{CN}}\right.$, $\mathrm{H}_{\mathrm{CC}}$ ). (B) AA sequence identity of the $\mathrm{H}_{\mathrm{CN}}$ domains of BoNT/A, BoNT/B, and TeNT. (C) Reducing $10 \%$ SDS-PAGE analysis of the 12 novel deletion mutants and chimeras (detection by Coomassie stain). (D) Secondary structure estimation of all mutants by CD-spectroscopy. Proportion of alpha-helices, beta-sheet, turn, and random coil is given in \%.

A main function of the $\mathrm{H}_{\mathrm{CN}}$ domain besides contributing to N-glycan binding of SV2 in BoNT/A might be the correct positioning of the $\mathrm{H}_{\mathrm{CC}}$ domain relative to the remaining $\mathrm{LH}_{\mathrm{N}}$ of BoNT to provide access of the synaptic protein receptor to its binding pocket as well as to facilitate a subsequent $\mathrm{pH}$-dependent insertion of $\mathrm{H}_{\mathrm{N}}$ into the vesicle membrane. Proteins of similar size but different folding, which could act as a rigid spacer, cannot adopt that role. In summary, these data progress the understanding of the $\mathrm{H}_{\mathrm{CN}}$ domain and its role in the mechanism of action of CNTs.

\section{Results}

\subsection{Generation of $H_{C N}$ Deletion Mutants and Hybrids of BoNT/A, B and TeNT}

Crystal structures of BoNT/A, BoNT/B and TeNT holotoxins, primary sequence alignments, and biochemical data were used to define the sequences comprising the $\mathrm{H}_{\mathrm{CN}}$ domains (Figures 1 and 2A). The $\mathrm{H}_{\mathrm{CN}} \mathrm{A}$ is defined from $\mathrm{K} 871-\mathrm{N} 1093, \mathrm{H}_{\mathrm{CN}} \mathrm{B}$ covers $\mathrm{S} 858-\mathrm{Y} 1080$, and $\mathrm{H}_{\mathrm{CN}} \mathrm{T}$ spans from I880-I1111. At first, mutants of BoNT/A, BoNT/B, and TeNT were constructed lacking their $\mathrm{H}_{\mathrm{CN}}$ domains, yielding scAA-A $\Delta$ K871-N1093, scBB-B $\Delta$ S858-Y1080, and scTT-T $\Delta$ I880-I1111.

Due to the high amino acid (AA) sequence identity of $52 \%$ between $\mathrm{H}_{\mathrm{CN}} \mathrm{A}$ and $\mathrm{H}_{\mathrm{CN}} \mathrm{B}$ as well as to $\mathrm{H}_{\mathrm{CN}} \mathrm{T}$ (33\% and $35 \%$, respectively, Figure $2 \mathrm{~B}$ ) and a highly similar fold as reflected by DALI Z-scores $>39.5$, we attempted to swap $\mathrm{H}_{\mathrm{CN}}$ domains between the three neurotoxins yielding six full-length hybrid toxins (Figure 2A).

Additionally, the $\mathrm{H}_{\mathrm{CN}}$ domain of BoNT/A was substituted with non-clostridial polypeptides of similar size but different conformation like the $26 \mathrm{kDa}$ green fluorescent protein (GFP), the $21 \mathrm{kDa}$ dihydrofolate reductase (DHFR), or a 12 amino acid long peptidic GlySer-linker (L12).

The three deletion mutants lacking $\mathrm{H}_{\mathrm{CN}}$ (AA-A, BB-B, TT-T; a capital letter according to the serotype origin was assigned to each of the four domains $\mathrm{LC}, \mathrm{H}_{\mathrm{N}}, \mathrm{H}_{\mathrm{CN}}$, and $\mathrm{H}_{\mathrm{CC}}$ ) and all full-length hybrids were recombinantly expressed as single-chain (sc) proteins in Escherichia coli. Changes in molecular weight due to domain deletion (e.g., scAA-A, $124 \mathrm{kDa}$; scBB-B, $127 \mathrm{kDa}$; scTT-T, $126 \mathrm{kDa}$ ) or exchanged domains are clearly visible by SDS-PAGE analysis (Figure 2C). All deletion mutants and hybrids were isolated as soluble proteins in good purity by a single step affinity chromatography. Protein yields ranged from $0.02-5 \mathrm{mg} / \mathrm{L}$ culture volume. Highest yield was obtained for the wild-type 
proteins scTTTT with $5 \mathrm{mg} / \mathrm{L}$ followed by scBBBB $(1.5 \mathrm{mg} / \mathrm{L})$ and scAAAA $(0.5 \mathrm{mg} / \mathrm{L})$. Removal of $\mathrm{H}_{\mathrm{CN}}$ domain dropped yield for scBB-B to $0.02 \mathrm{mg} / \mathrm{L}$ and for scTT-T to $0.5 \mathrm{mg} / \mathrm{L}$, but increased yield of scAA-A to $1 \mathrm{mg} / \mathrm{L}$. Apart from scBBTB, all other full-length mutants were isolated with yields between $0.15-2.0 \mathrm{mg} / \mathrm{L}$. This indicates that the domain exchange in the majority of mutants did not impair the tertiary structure and solubility of the CNTs.

However, protein yield is only an indirect measure for correct protein folding. We therefore conducted secondary structural analysis of the mutants using CD spectroscopy, since deletion of the whole $\mathrm{H}_{\mathrm{CN}}$ domain, its replacement either by another $\mathrm{H}_{\mathrm{CN}}$ domain, or an even non-CNT domain like GFP or DHFR generates a completely novel protein with novel characteristics like individual melting temperature. The alpha-helical content of the three wild-type CNTs (scAAAA, scBBBB, and scTTTT) ranges between 19-24\% (Figure 2D), which is in good accordance with their full-length crystal structures (Figure 1) [8-10]. Alpha-helices are almost exclusively found in $\mathrm{LC}$ and $\mathrm{H}_{\mathrm{N}}$, but hardly in $\mathrm{H}_{\mathrm{C}}$. Therefore, the absolute alpha-helical content should not alter in the deletion mutants and in the CNT hybrids, but the relative alpha-helical content will increase due to the reduction of molecular weight by $25 \mathrm{kDa}$. Indeed, the hybrids display an alpha-helical content from 13-28\%, which is comparable to their wild-type counterparts. As expected, scAA-A and scBB-B show an increased proportion of $37 \%$ and $28 \%$ compared to $19 \%$ and $25 \%$ of scAAAA and scBBBB, respectively. Beta-sheet content and turns are rather variable over all constructs, but the random coil, a clear indicator of unfolded protein, is very narrow between $26-36 \%$. Since the purity of some constructs like scBBTB is below $90 \%$, one also has to consider the impurities' effect on the outcome. Altogether, secondary structural analysis of the mutants using CD spectroscopy revealed no unfolded protein or even major changes in secondary structure. Minor changes cannot be excluded and will be only exhibited by X-ray crystallography, but are inherent when generating novel molecules. Functional analysis described below will shed further light on the structural integrity of the mutants.

\subsection{Determination of Residual Biological Activity Using the Mouse Phrenic Nerve Hemidiaphragm (MPN) Assay}

The residual biological activity of all mutants was tested using the mouse phrenic nerve hemidiaphragm (MPN) assay, which constitutes an excellent system to determine the pharmacodynamic properties without performing an animal experiment [52]. First, individual dose-response curves were generated for the three wild-type proteins scAAAA, scBBBB, and scTTTT, to which power functions for calculating the relative toxicity of mutants were fitted. scAAAA displays the highest potency, while scBBBB is about 2.3-fold less potent than scAAAA (Figure 3A confirming previous results [53]). scTTTT is the least potent neurotoxin in the MPN assay (32-fold less potent than scAAAA) [54], because the motoneuron of the hemidiaphragm preparation constitutes TeNT's physiological uptake site into vesicles with $\mathrm{pH}$-neutral lumen, but its main site of action is the inhibitory interneuron absent in the MPN assay. At higher concentrations, a small fraction of TeNT seems to be taken up into acidifying vesicles, thereby releasing TeNT LC into the cytosol of the motoneuron and blocking acetylcholine release like BoNT. 


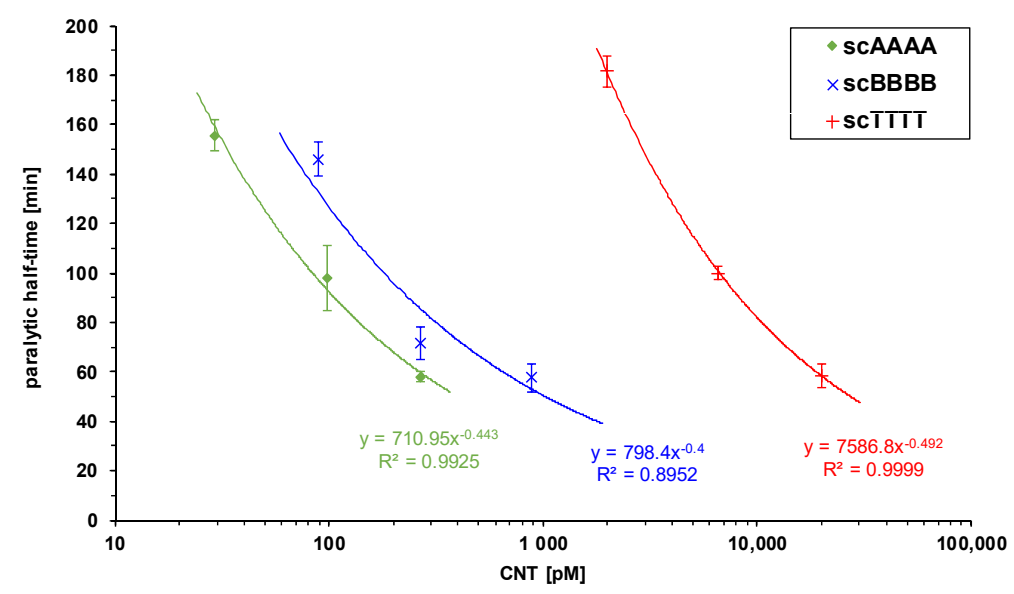

(A)

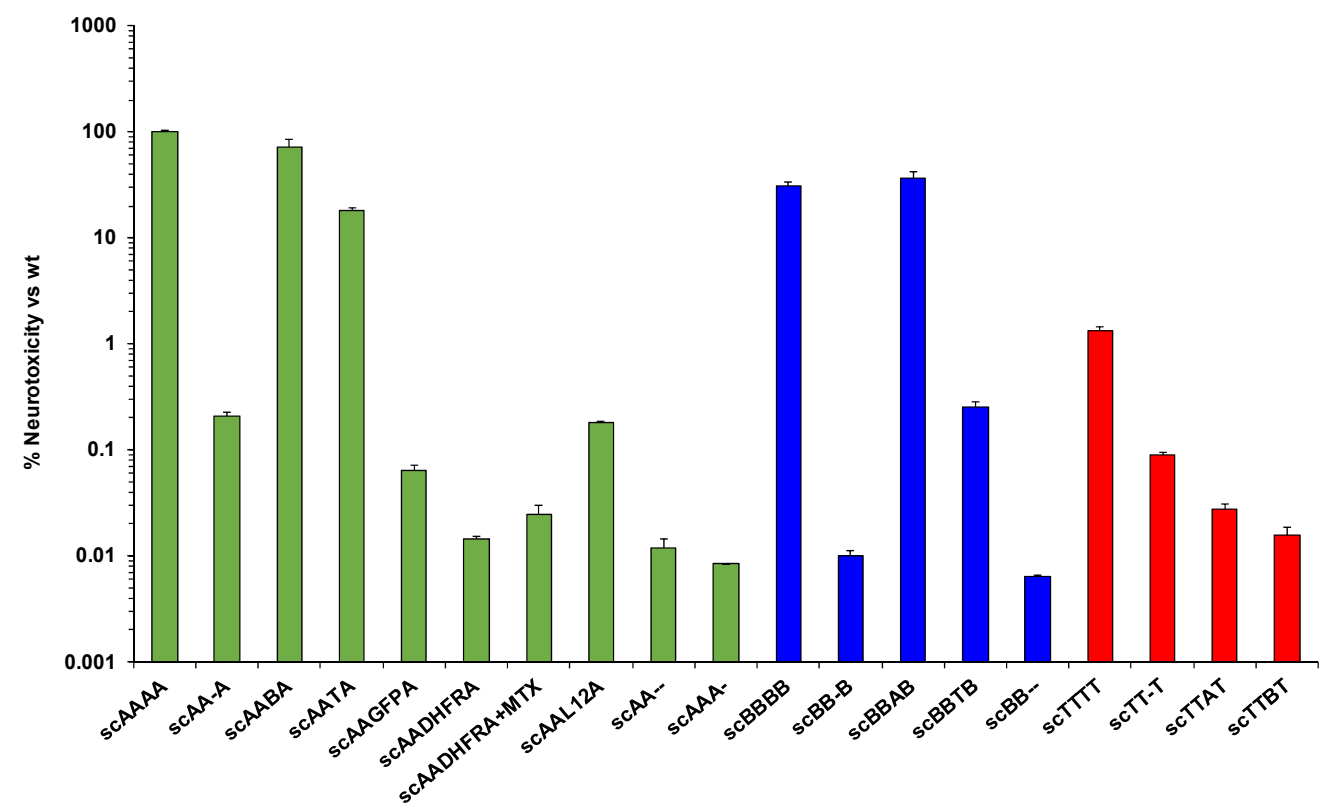

(B)

Figure 3. Determination of biological activity of mutants by the MPN assay. CNTs were added to electrically stimulated mice hemidiaphragm preparations, isometric contractions were recorded, and the time required to decrease the amplitude to $50 \%$ of the starting value was determined. (A) Dose-response curves of wild-type constructs scAAAA, scBBBB, and scTTTT with their corresponding fitted power functions ( $n=3-4$ biol. replicates; mean \pm SD). (B) Neurotoxicity of mutants. All measurements ( $\mathrm{n}=3-4$ biol. replicates; mean $\pm \mathrm{SD}$ ) are referenced to scAAAA dose response power function; MTX, $0.6 \mu \mathrm{M}$ methotrexate (induces rigid structure of DHFR).

Deletion of the $\mathrm{H}_{\mathrm{CN}}$ domain in TeNT reduced the biological activity of scTT-T in the hemidiaphragm tissue about 13-fold compared to its wild-type scTTTT, whereas scAA-A and scBB-B deletion mutants displayed 480-fold and 4000-fold decreased activity compared to their respective wild-type forms. Using scAAAA as common reference, scTT-T maintains nine-fold higher potency than scBB-B $(0.09 \mathrm{vs}$. $0.01 \%)$ and is only $50 \%$ less potent than scAA-A $(0.21 \%$; Figure $3 \mathrm{~B})$. Replacement of the $\mathrm{H}_{\mathrm{CN}}$ domain in TeNT by $\mathrm{H}_{\mathrm{CN}} \mathrm{A}$ and $\mathrm{H}_{\mathrm{CN}} \mathrm{B}$ decreased the potency of scTTAT and scTTBT further to $0.027 \%$ and $0.016 \%$, respectively. In contrast, swapping $\mathrm{H}_{\mathrm{CN}}$ domains between BoNT/A and $\mathrm{B}$ hardly impaired activity of scAABA $(72 \%)$, while scBBAB even profits from insertion of $\mathrm{H}_{\mathrm{CN}} \mathrm{A}(106 \%$ of scBBBB potency). The substitution of $\mathrm{H}_{\mathrm{CN}} \mathrm{A}$ by $\mathrm{H}_{\mathrm{CN}} \mathrm{T}$ was tolerated; scAATA still displayed $18 \%$ potency of wild-type, but potency of scBBTB was drastically reduced to $0.25 \%$ of scAAAA. 
Additionally, the $\mathrm{H}_{\mathrm{CN}}$ domain of BoNT/A was substituted with non-clostridial polypeptides of similar size like the $26 \mathrm{kDa}$ GFP, the $21 \mathrm{kDa}$ DHFR, or the peptidic linker L12. Whereas the scAAL12A construct behaves like the BoNT/A deletion mutant scAA-A $(0.18 \%)$, the substitution of the $\mathrm{H}_{\mathrm{CN}} \mathrm{A}$ domain by the rigid $\beta$-barrel structure of GFP decreased activity. Despite DHFR being a flexible protein, it is not well tolerated, as can be seen by the potency of $0.015 \%$ of scAADHFRA. Freezing the DHFR conformation by the addition of $0.6 \mu \mathrm{M}$ methotrexate (MTX), a chemotherapy agent that acts as an immune system suppressant by inhibiting tetrahydrofolate synthesis by DHFR, potency of scAADHFRA increases to $0.025 \%$, which is according to a paired $t$-test of these two experiments non-significant $(P=0.183)$. MTX on its own did not influence neurotransmitter release. Deleting the entire $50 \mathrm{kDa} \mathrm{H}_{\mathrm{C}} \mathrm{A}$ domain (scAA-) yields a nearly inactive molecule $(0.012 \%$ potency; Figure $3 \mathrm{~B})$, as demonstrated earlier [55].

\subsection{Pull-Down Assays Employing GST-rSV2C 454-579, GST-rSyt-II 1-61 and ghSV2CLD-Fc}

The previous demonstration that isolated $\mathrm{H}_{\mathrm{CC}} B$ interacts with its protein receptors Syt-I/-II [39] as well as the identification of the Syt-II binding site in BoNT/B at the tip of the $\mathrm{H}_{\mathrm{CC}}$ domain $[27,48,49]$ sets the ideal tool to confirm the correct folding of the $\mathrm{H}_{\mathrm{CC}}$ domain within the deletion mutant scBB-B and the corresponding BoNT/B hybrids as well as to verify the integrity of the receptor binding site. Surprisingly, the deletion mutant scBB-B lacks any interaction with its protein receptor Syt-II (Figure 4). In contrast, the hybrids BBAB and BBTB display a binding of $26.4 \mathrm{~mol} \%$ and $17.2 \mathrm{~mol} \%$ to GST-Syt-II 1-61, respectively, compared to $22.2 \mathrm{~mol} \%$ of BoNT/B wild-type, indicating an intact $\mathrm{H}_{\mathrm{CC}} \mathrm{B}$ and a fully functional Syt-binding site.

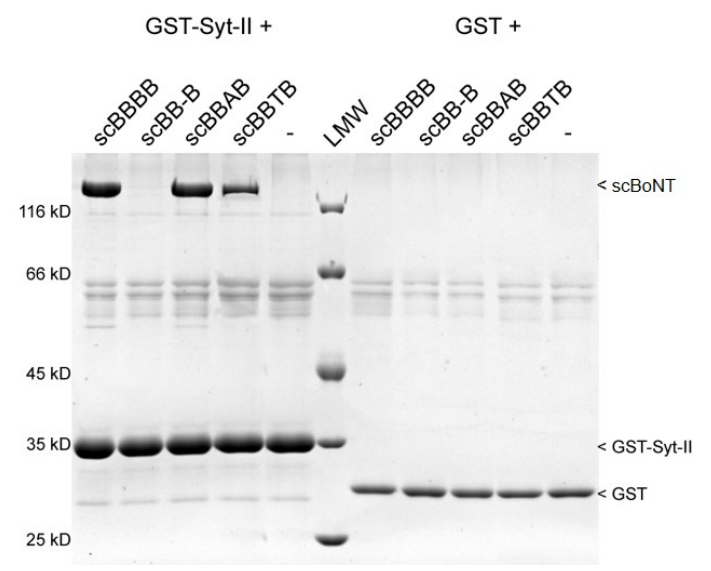

(A)

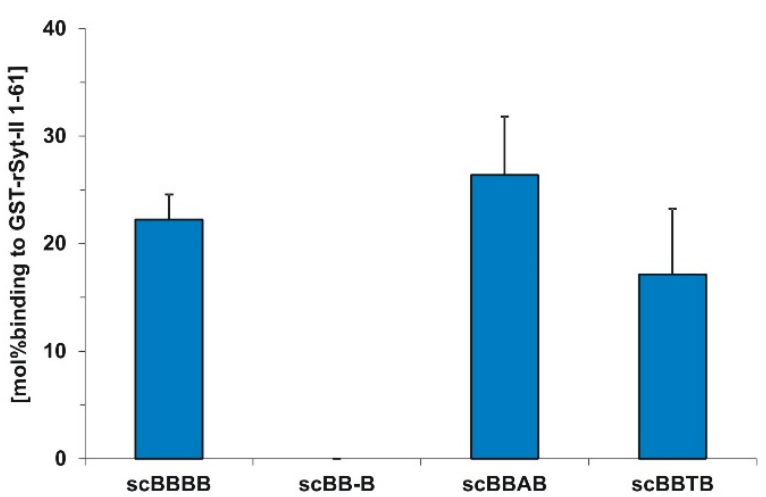

(B)

Figure 4. GST-pull-down assay of BoNT/B mutants employing GST-Syt-II 1-61. (A) GST-Syt-II 1-61 fusion-protein, protein receptor of BoNT/B was immobilized on glutathione-sepharose beads and subsequently incubated with the indicated wild-type/mutants $(250 \mathrm{nM})$ for $2 \mathrm{~h}$ at $4{ }^{\circ} \mathrm{C}$. After washing, proteins bound to the solid phase were analyzed by SDS-PAGE and visualized by Coomassie staining. Parallel experiments with GST served as negative controls. (B) Quantitative analysis of wild-type/mutants bound to GST-Syt-II 1-61 ( $\mathrm{n}=3$ biol. replicates; mean $\pm \mathrm{SD}$ ). The value "mol\% binding" is the ratio of band intensity of the respective GST fusion protein as immobilized bait and the bound BoNT as ligand/prey corrected by the molecular weight ratio of BoNT vs. GST fusion protein. Unspecific ligand binding to GST was subtracted.

Analogously, the correct folding of the $\mathrm{H}_{\mathrm{CC}}$ domain within the deletion mutant scAA-A and the BoNT/A hybrids was verified employing non-glycosylated GST-rSV2C 454-579. Here, the deletion mutant scAA-A still displays interaction with its protein receptor SV2C albeit with lower affinity than BoNT/A wild-type $(0.76 \mathrm{~mol} \%$ vs. $7.1 \mathrm{~mol} \%$; Figure 5). Binding of the hybrids scAABA and scAATA to GST-rSV2C $454-579$ is moderately impaired ( $2.0 \mathrm{~mol} \%$ and $3.5 \mathrm{~mol} \%)$, indicating an intact 
folded $\mathrm{H}_{\mathrm{CC}} \mathrm{A}$ in both proteins and a largely functional and accessible SV2C-binding site. The hybrids with the non-clostridial $\mathrm{H}_{\mathrm{CN}}$ substitutions scAAGFPA and scAADHFRA display hardly detectable binding to GST-rSV2C 454-579. As a control, the isolated $\mathrm{H}_{\mathrm{C}} \mathrm{A}$ fragment showed $13 \mathrm{~mol} \%$ binding to GST-rSV2C, twice as much as full-length scAAAA. Binding of the isolated $\mathrm{H}_{\mathrm{CC}} \mathrm{A}$ to GST-rSV2C was almost stoichiometric with $65 \mathrm{~mol} \%$, which might be explained by the increased rotational freedom, an improved accessibility of SV2C to its binding site (no shielding by LC and $\mathrm{H}_{\mathrm{N}}$ ), or unspecific interactions with the exposed hydrophobic $\mathrm{H}_{\mathrm{CN}}$ interface.

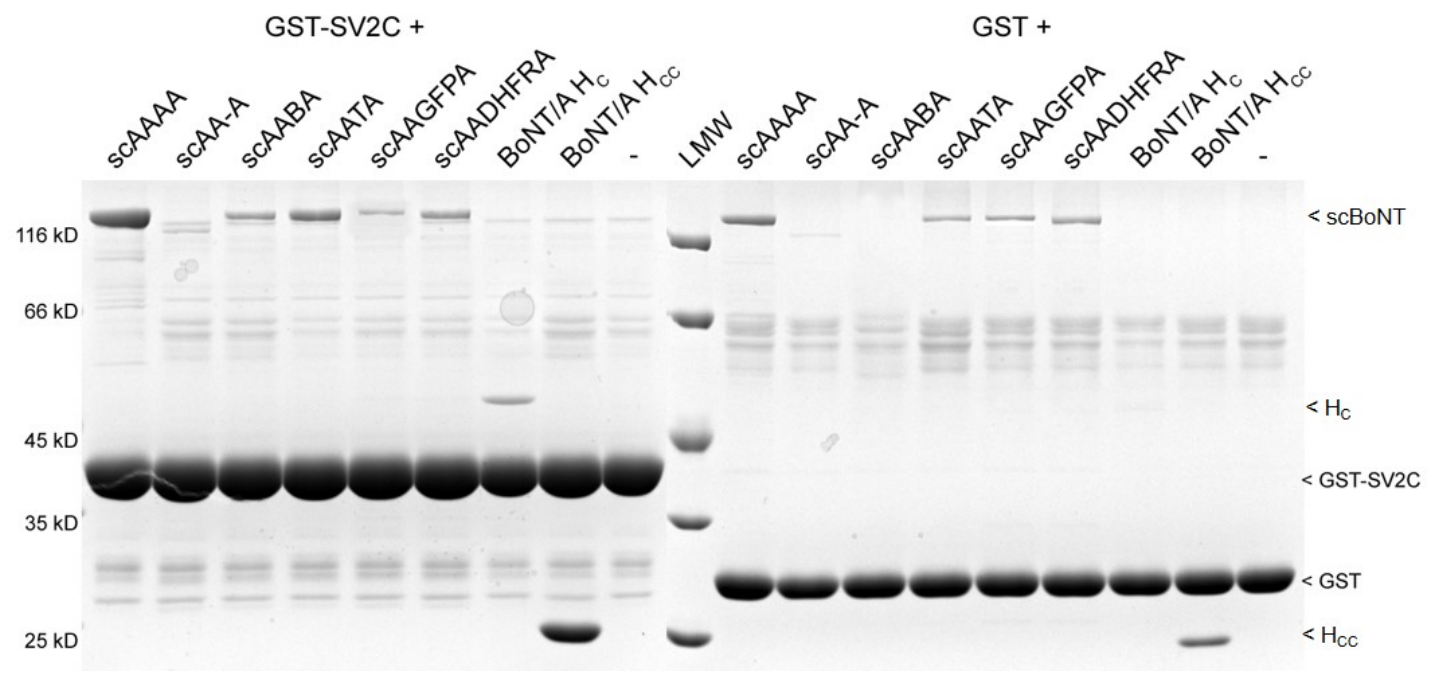

(A)

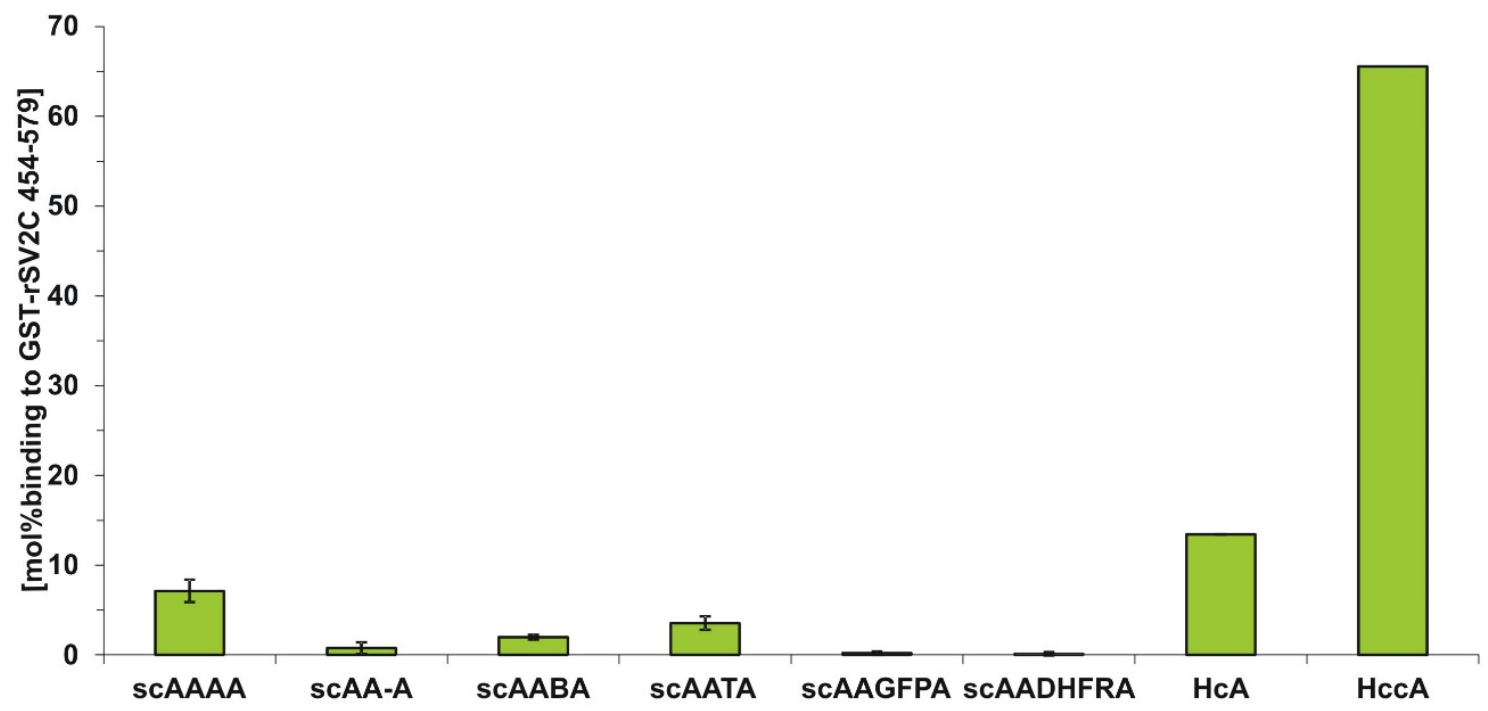

(B)

Figure 5. GST-pull-down assays of BoNT/A mutants employing GST-rSV2C 454-579. (A) GST-rSV2C 454-579 fusion-protein, protein receptor of BoNT/A (Luminal domain 4 of rat synaptic vesicle protein 2C), was immobilized on glutathione-sepharose beads and incubated with indicated wild-type/mutants $(250 \mathrm{nM})$ for $2 \mathrm{~h}$ at $4{ }^{\circ} \mathrm{C}$. Proteins bound to the solid phase were analyzed by SDS-PAGE and visualized by Coomassie staining. Parallel experiments with GST only served as negative controls. (B) Quantitative analysis of wild-type/mutants bound to GST-rSV2C 454-579 ( $\mathrm{n}=3$ biol. replicates; mean \pm SD). The value "mol\% binding" is the ratio of band intensity of the respective GST fusion protein as immobilized bait and the bound BoNT as ligand/prey corrected by the molecular weight ratio of BoNT vs. GST fusion protein. Unspecific ligand binding to GST was subtracted. 
Recently, we showed the importance of the complex glycan-branch at N559 of SV2C-LD4, adding a third anchor point beside a ganglioside and the SV2C-LD4 peptide, for BoNT/A neuronal cell surface binding and uptake [47]. Since the N559-glycan was shown to bind predominantly to residues assigned to the $\mathrm{H}_{\mathrm{CN}} \mathrm{A}$ domain [16], we deepened our analysis and employed our glycosylated human SV2C-LD4 Fc fusion protein gSV2CLD-Fc in a pull-down assay to investigate the binding of the scAA-A deletion mutant. As seen previously, BoNT/A wild-type showed almost stoichiometric high-affinity binding to gSV2CLD-Fc wild-type (Figure 6). Preventing the glycosylation of N559 by exchanging S561 of the PNG motif N-X-S/T to alanine reduced the binding of BoNT/A wild-type by 10-fold, reproducing our previous results about the importance of the N559-glycan [47]. Since residue S561 is part of the $\beta$-strand mediating the protein-protein interaction with $\mathrm{H}_{\mathrm{CC}} \mathrm{A}$, we mutated $\mathrm{S} 561$ also to glutamate to destroy that interaction. Indeed, BoNT/A wild-type hardly bound to gSV2CLD-Fc S561E. In contrast to BoNT/A wild-type, binding of scAA-A to any gSV2CLD-Fc was close to the limit of detection of Coomassie staining. Since scAA-A displays only $10 \%$ of BoNT/A wild-type binding to non-glycosylated GST-rSV2C 454-579, it is understandable that such a signal cannot be seen considering the weak signal for BoNT/A wild-type binding to gSV2CLD-Fc S561A. Surprisingly, the presence of the N559-glycan in gSV2CLD-Fc wild-type does not rescue absence of $\mathrm{H}_{\mathrm{CN}} \mathrm{A}$, but rather destabilizes protein-protein interaction with scAA-A (Figure 6).

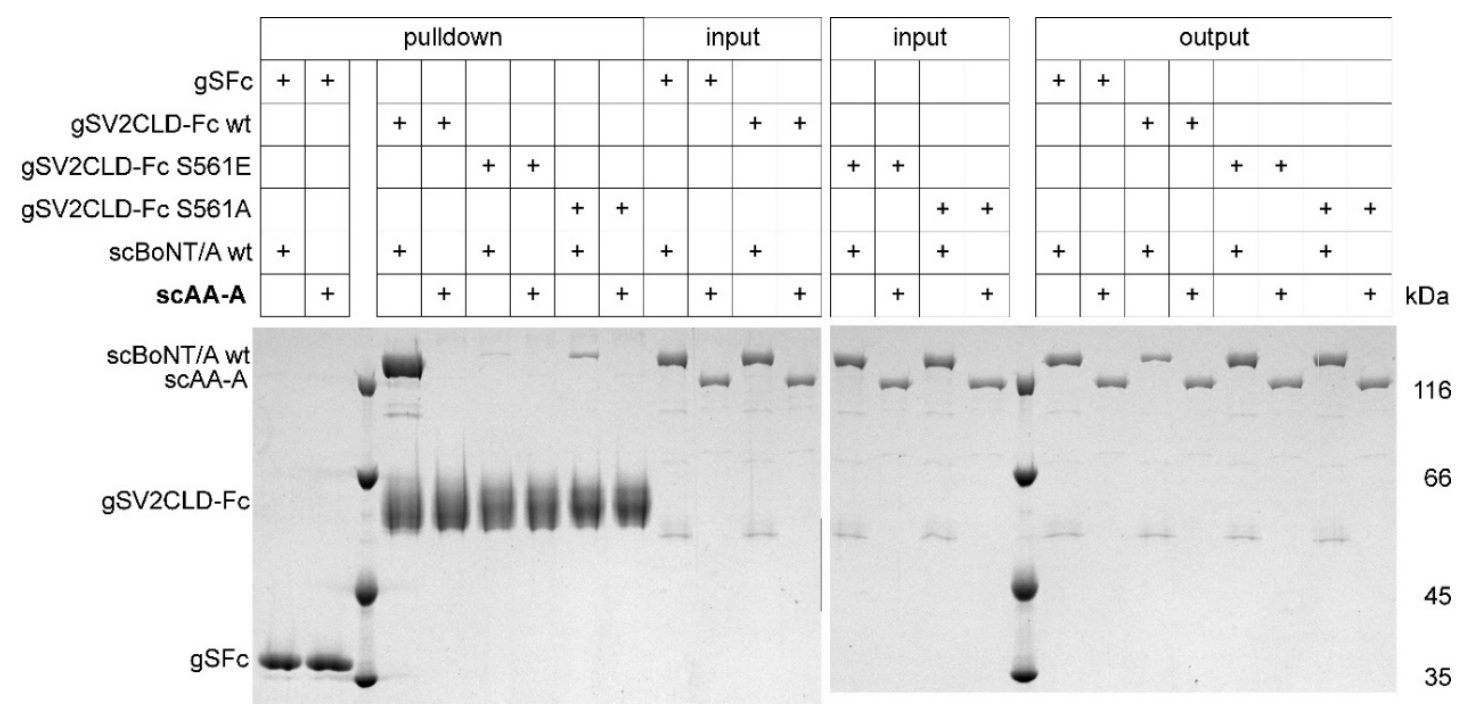

Figure 6. Pull-down assay with glycosylated SV2C and scAA-A and BoNT/A wild-type. 100 pmol of wild-type and mutant glycosylated gSV2CLD-Fc were immobilized to protein G sepharose matrix and incubated with $250 \mathrm{nM}$ (50 pmol, input) of scAA-A or BoNT/A wild-type, respectively, for $2 \mathrm{~h}$ at $4{ }^{\circ} \mathrm{C}$. After removal of supernatant (output) and washing of the beads, bound proteins (pulldown) were visualized by SDS-PAGE and Coomassie Blue staining.

\subsection{Ganglioside Binding of CNT Deletion Mutants and Hybrids in Liposome Binding Assay}

To analyze the ability of the deletion mutants and hybrids to bind to gangliosides, isolated polysialo-ganglioside GT1b was incorporated into liposomes to provide a membranous environment.

All BoNT/A-based hybrids as well as the deletion mutant sAA-A showed ganglioside binding virtually indistinguishable from BoNT/A wild-type (Figure 7). Hence, absence of $\mathrm{H}_{\mathrm{CN}} \mathrm{A}$ or its replacement by other domains did not influence functionality of the conserved GBS in $\mathrm{H}_{\mathrm{CC}} \mathrm{A}$. As control, the $\mathrm{LH}_{\mathrm{N}}$ of BoNT/A, AA-, lacking the complete receptor binding domain $\mathrm{H}_{\mathrm{C}} \mathrm{A}$ was analyzed and showed only background binding as expected. 


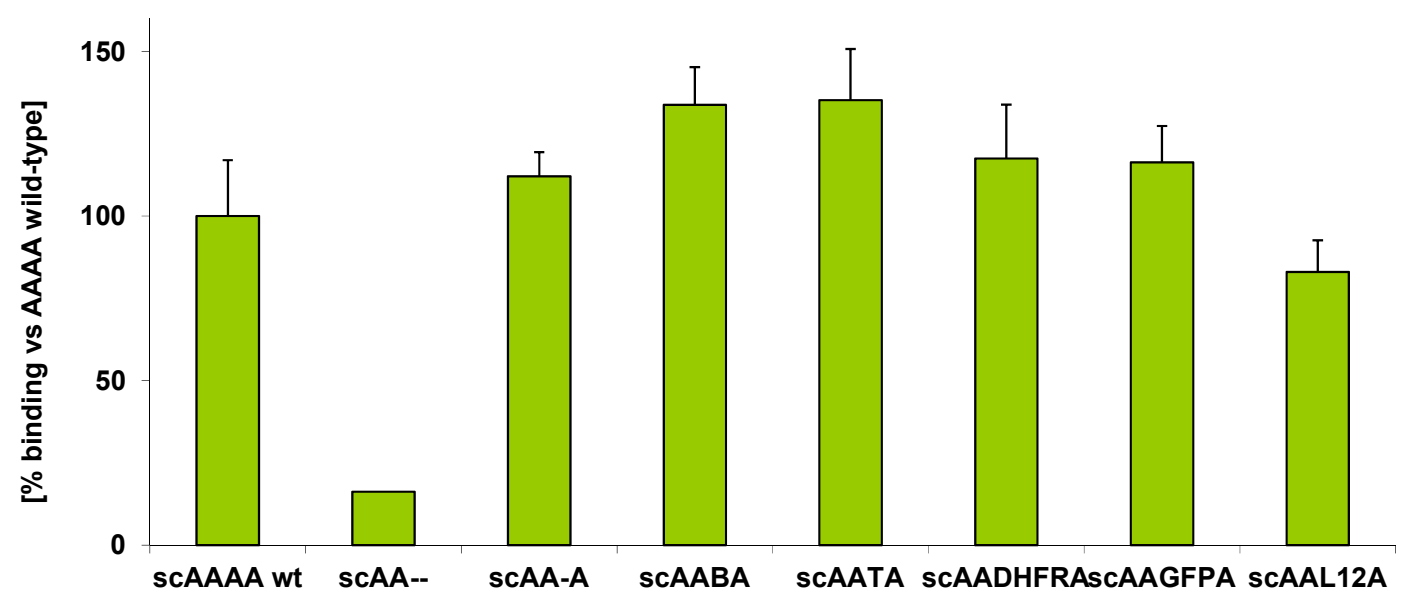

(A)

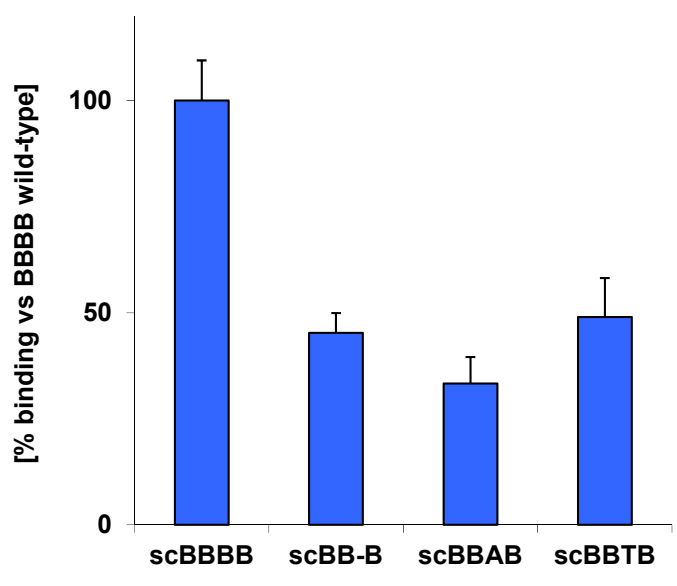

(B)

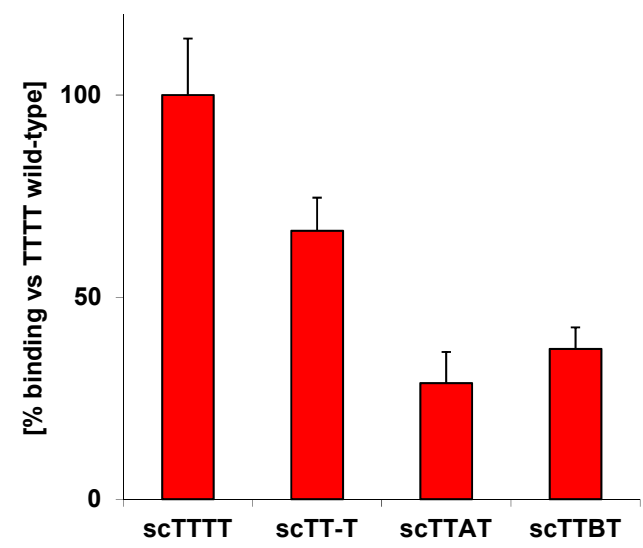

(C)

Figure 7. Ganglioside binding of CNT deletion mutants and hybrids in liposome binding assay. An emulsion of GT1b-functionalized RhodamineB-DHPE liposomes was incubated with the respective CNTs for $2 \mathrm{~h}$ at RT. Bound CNTs were sedimented, and incorporated fluorophore RhodamineB was liberated upon Triton X-100 lysis and determined by fluorescence microplate reader. (A) Ganglioside binding of BoNT/A deletion mutants and hybrids ( $n=3$ biol. replicates \pm SD). (B) Ganglioside binding of BoNT/B deletion mutants and hybrids ( $n=2$ biol. replicates \pm SD). (C) Ganglioside binding of TeNT deletion mutants and hybrids (scTTTT $n=7, \operatorname{scTT}-\mathrm{T} n=5$, scTTAT and scTTBT $n=3$ biol. replicates; mean $\pm \mathrm{SD})$.

BoNT/B- and TeNT-based hybrids as well as the deletion mutants showed all binding to liposome-incorporated GT1b albeit at clearly reduced levels of 30-65\% compared to wild-type BoNT/B and TeNT.

\subsection{Secondary Structure Analyses of the Deletion Mutant AA-A}

The determination of secondary structure by $\mathrm{CD}$ spectrometry provides a powerful technique to analyze mutants in comparison to their wild-type molecule. To verify whether $\mathrm{H}_{\mathrm{CC}} \mathrm{A}$ within the deletion mutant scAA-A adopts the same fold as isolated $\mathrm{H}_{\mathrm{CC}} \mathrm{A}$, which shows high affinity binding towards GST-rSV2C 454-579 (Figure 5), the CD spectrum of scAA-A was determined (Figure 8). Subsequently, AA- lacking the complete receptor binding domain $\mathrm{H}_{\mathrm{C}} \mathrm{A}$, the isolated $\mathrm{H}_{\mathrm{CC}} \mathrm{A}$, and a stoichiometric mixture of both mimicking AA-A were determined. In accordance with the BoNT/A crystal structure, $\mathrm{H}_{\mathrm{CC}} \mathrm{A}$ displays predominantly $\beta$-sheet, turns, and random coil and hardly helical 
parts (Figure 8). Accordingly, its molar ellipticity signal was small. Isolated AA- displays a high content of $\alpha$-helices, especially due to the long $\alpha$-helices in the translocation domain $\mathrm{H}_{\mathrm{N}}$, which is visible in the minima at 210 and $220 \mathrm{~nm}$ of its spectrum (Figure 8). Measurement of AA-A yields a minimally lower molar ellipticity than AA-, which indicates a higher $\beta$-sheet content due to the presence of the $\mathrm{H}_{\mathrm{CC}} \mathrm{A}$. Finally, the trace of a stoichiometric mixture of AA- and HccA nicely overlaps with that of AA-A, demonstrating that isolated $\mathrm{AA}-$ and $\mathrm{H}_{\mathrm{CC}} \mathrm{A}$ in total comprise the same secondary structure as AA-A on its own. A theoretical addition of the spectra of $\mathrm{H}_{\mathrm{CC}} \mathrm{A}$ and $\mathrm{AA}-$ yielded a spectrum virtually indistinguishable from that of the stoichiometric mixture of AA- and HccA.

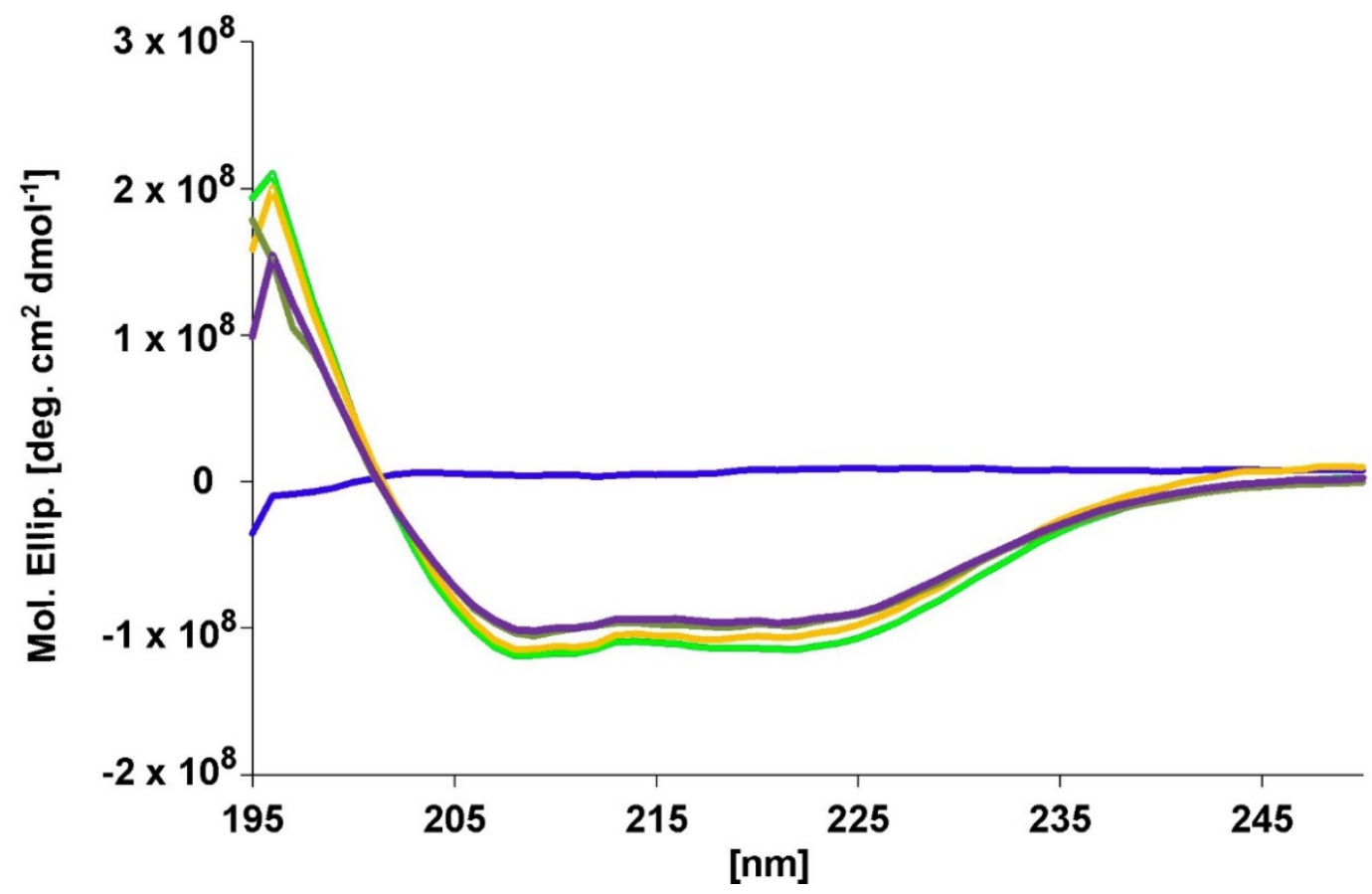

Figure 8. Far-UV spectra of free $\mathrm{H}_{\mathrm{CC}} \mathrm{A}$ (blue trace), scAA-(green trace), scAA-A (lime trace), and a stoichiometric mixture of $\mathrm{H}_{\mathrm{CC}} \mathrm{A} / \mathrm{scAA}$ - (purple trace) as well as the arithmetical combination of $\mathrm{H}_{\mathrm{CC}} \mathrm{A}$ and $\mathrm{AA}-$ (orange trace). Accordingly, the combination of $\mathrm{H}_{\mathrm{CC}} \mathrm{A}$ and scAA- yielded a spectrum similar to that of AA-A.

\section{Discussion}

The $150 \mathrm{kDa}$ CNTs are folded into four distinct domains and to three of those, LC, $\mathrm{H}_{\mathrm{N}}$, and $\mathrm{H}_{\mathrm{CC}}$, a role in the mechanism of action at the neuronal site has been ascribed and experimentally proven [13,56-58]. This evidence is missing for the $25 \mathrm{kDa} \mathrm{H}_{\mathrm{CN}}$ domain sandwiched between the translocation domain $\mathrm{H}_{\mathrm{N}}$ and the $\mathrm{H}_{\mathrm{CC}}$ domain comprising receptor binding sites.

Although an isolated BoNT/A $\mathrm{H}_{\mathrm{CN}}\left(\mathrm{EGFP}_{\mathrm{H}} \mathrm{H}_{\mathrm{CN}} / \mathrm{A}\right)$ binds to the plasma membrane of neurons in discrete spots identified as sphingomyelin-enriched membrane microdomains without being internalized [50], a directed mutagenesis analysis of a site suggested for interaction with PIP did not confirm this hypothesis [17]. In the latter study, also a BoNT/A $\mathrm{H}_{\mathrm{CN}}$ deletion mutant was generated, replacing the segment I874-Q1091 by two glycines $\left(=\mathrm{rA} \Delta \mathrm{H}_{\mathrm{CN}}\right)$ and subsequently characterized in detail. Its lethality was reduced 33,000-fold as well as its biological activity in primary neuronal cultures, clearly demonstrating the dramatic loss in the overall biological activity upon deleting the $\mathrm{H}_{\mathrm{CN}}$ from BoNT/A. Their results are in accordance with the 500-fold reduction of biological activity of our deletion mutants scAA-A and scAAL12A (Figure 3B). Their $\mathrm{rA} \Delta \mathrm{H}_{\mathrm{CN}}$ lacked high-affinity binding to rat cultured cerebellar granule neurons at $4{ }^{\circ} \mathrm{C}$ as well as subsequent internalization [17]. It remains unclear whether the $\mathrm{rA} \Delta \mathrm{H}_{\mathrm{CN}}$ maintained its ability to bind to complex polysialo-gangliosides. Our deletion mutants scAA-A or scAAL12A showed binding to GT1b incorporated in liposomes similar to BoNT/A wild-type 
(Figure 7A), indicating that the lack of $\mathrm{H}_{\mathrm{CN}} \mathrm{A}$ does not interfere with ganglioside binding taking place in $\mathrm{H}_{\mathrm{CC}} \mathrm{A}$. In contrast, the protein-protein interaction of scAA-A with its non-glycosylated protein receptor SV2C was reduced about 10-fold (Figure 4A), although the SV2C binding site was allocated to a $\beta$-strand in $\mathrm{H}_{\mathrm{CC}} \mathrm{A}[15,45]$ present in scAA-A. Similar findings were obtained for $\mathrm{rA} \Delta \mathrm{H}_{\mathrm{CN}}$ [17]. However, the SV2C site is in close proximity to the $\mathrm{H}_{\mathrm{CN}}$ interface and in the absence of $\mathrm{H}_{\mathrm{CN}} \mathrm{A}$ as in scAA-A the translocation domain $\mathrm{H}_{\mathrm{N}}$ might shield access to the SV2 site in $\mathrm{H}_{\mathrm{CC}} \mathrm{A}$ (Figure 1). In contrast, in isolated $\mathrm{H}_{\mathrm{CC}} \mathrm{A}$, the $\mathrm{SV} 2 \mathrm{C}$ site is freely accessible, explaining its high affinity binding to GST-rSV2C 454-579 (Figure 4A). This obstructing effect in scAA-A is even further pronounced by testing binding to glycosylated SV2C (Figure 5). The high affinity interaction of BoNT/A wild-type with SV2C based upon the bidentate binding of the $\mathrm{N}$-glycan and two $\beta$-sheets of the quadrilateral SV2C helix cannot be established, since the N-glycan binding site mainly located in $\mathrm{H}_{\mathrm{CN}} \mathrm{A}$ is absent [16]. On top, the N-glycan's presence might hinder access of the two $\beta$-sheets of SV2C to its site in $\mathrm{H}_{\mathrm{CC}} \mathrm{A}$ directly next to $\mathrm{H}_{\mathrm{N}}$ even more.

We extended our study on the role of $\mathrm{H}_{\mathrm{CN}}$ beyond the work of Wang et al. [17] by analyzing the effect of deleting $\mathrm{H}_{\mathrm{CN}}$ also in BoNT/B and TeNT. Interestingly, scBB-B displays a 10-fold lower biological activity than scAA-A, whereas the biological activity of scTT-T at the motoneuron is in the range of that of the scAA-A deletion mutant. Since TeNT wild-type is just 13-fold more potent than scTT-T at the motoneuron, we speculate whether absence of $\mathrm{H}_{\mathrm{CN}} \mathrm{T}$ reduces uptake of scTT-T into neutral vesicles and subsequent retrograde axonal transport. Low potency of scBB-B could be caused by folding problems in $\mathrm{H}_{\mathrm{CC}} \mathrm{B}$ as illustrated by low protein yields and lack of detectable binding to its protein receptor Syt-II (Figure 4B). However, scBB-B still shows $40 \%$ binding towards GT1b-liposomes compared to BoNT/B wild-type and isolated $\mathrm{H}_{\mathrm{CC}} \mathrm{B}$ displays solid binding of Syt-I and -II [39]. Since the Syt binding site is located at the tip of $\mathrm{H}_{C C} B[27,48,49]$, its access is unlikely to be obstructed by $\mathrm{H}_{N}$ in scBB-B.

Besides deleting $\mathrm{H}_{\mathrm{CN}}$ in BoNT/A, BoNT/B, and TeNT holotoxins, we also attempted to swap $\mathrm{H}_{\mathrm{CN}}$ between the CNTs analyzed here. This approach was fueled by our previous studies in which either the whole $\mathrm{H}_{\mathrm{C}}$ fragment or just the $\mathrm{H}_{\mathrm{CC}}$ domain of BoNT/A, BoNT/B, and TeNT were successfully replaced with one of the other two types $[53,54]$. Replacement of the $\mathrm{H}_{\mathrm{CN}}$ domain in TeNT by $\mathrm{H}_{\mathrm{CN}} \mathrm{A}$ and $\mathrm{H}_{\mathrm{CN}} \mathrm{B}$ reduced the biological activity similarly to scTT-T by about $95 \%$, indicating that the sheer presence of a lectin-like fold of $25 \mathrm{kDa}$ does not contribute to the biological activity of TeNT (Figure 3B), which is in line with the position of conserved residues in the $\mathrm{H}_{\mathrm{CN}}$ domain. Based upon the primary sequence alignment of BoNT/A, B, and TeNT, the strictly conserved residues are highlighted in a BoNT/A $\mathrm{H}_{\mathrm{CN}}$ structure (Figure 9). Here, the majority of strictly conserved residues are at the hydrophobic core of $\mathrm{H}_{\mathrm{CN}}$ and dictate its overall fold. Only three strictly conserved residues (I931, N934, L1023, numbering according to BoNT/A) are in close proximity to $\mathrm{H}_{\mathrm{N}}$ and seem to interact. At the opposite interface, four strictly conserved residues (R947, P949, K950, W1013) seem to interact with $\mathrm{H}_{\mathrm{CC}}$. The majority of other inter-domain interactions are mediated by serotype specific residues explaining the low biological activity of the TeNT hybrids. However, which features in $\mathrm{H}_{\mathrm{CN}} \mathrm{T}$ fulfill these specific requirements is unclear. 


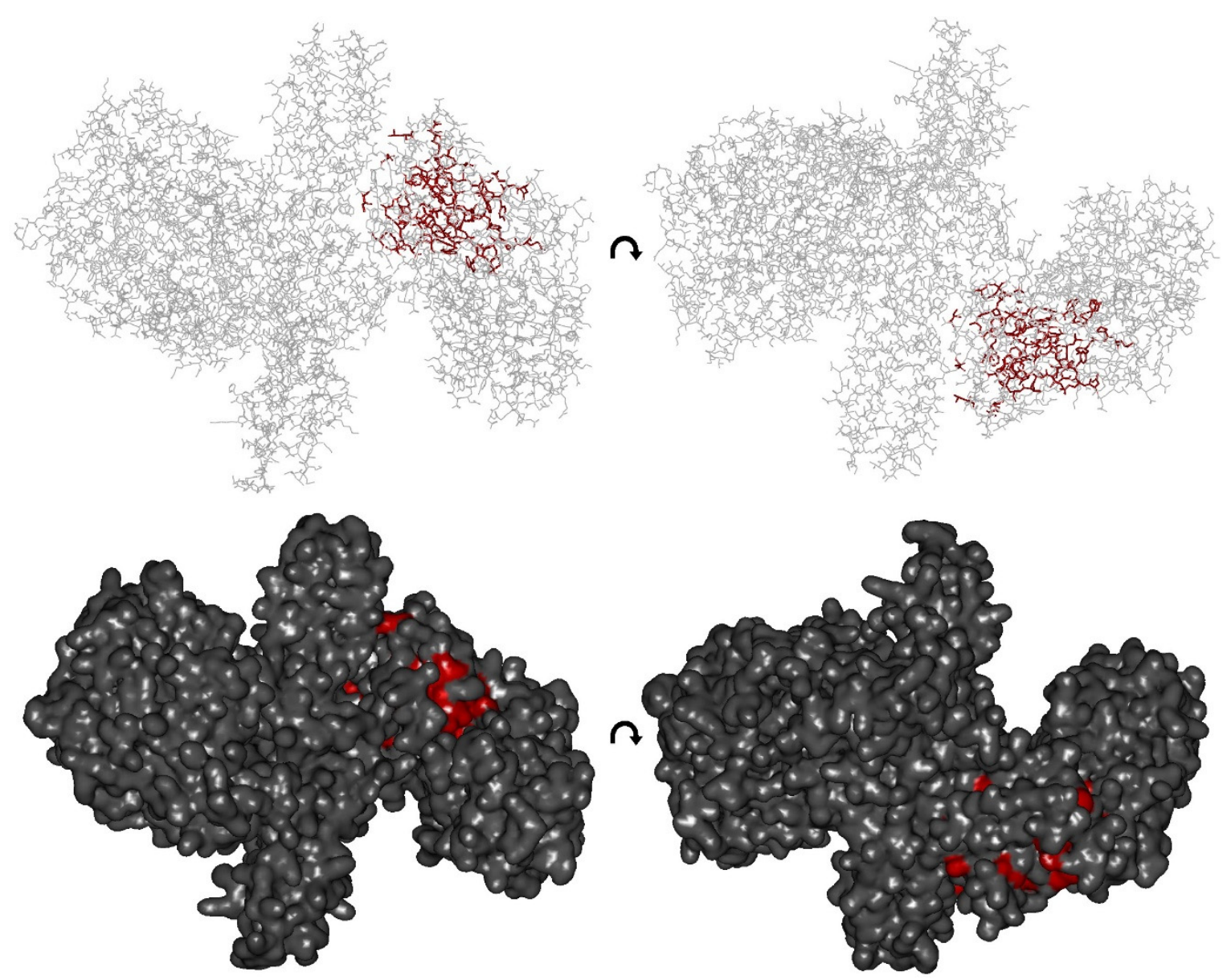

Figure 9. Strictly conserved residues in $\mathrm{H}_{\mathrm{CN}}$ of BoNT/A, B, and TeNT. Based upon primary sequence alignment of BoNT/A, B, and TeNT, strictly conserved residues are highlighted in red in the BoNT/A $\mathrm{H}_{\mathrm{CN}}$ structure (3BTA.pdb). Upper panel, stick representation, lower panel surface representation, BoNT/A shown with $180^{\circ}$ rotation. The majority of strictly conserved residues are at the hydrophobic core of $\mathrm{H}_{\mathrm{CN}}$ and dictate its overall fold. Only three strictly conserved residues (I931, N934, L1023, numbering according to BoNT/A) are in close proximity to $\mathrm{H}_{\mathrm{N}}$ and seem to interact. At the opposite interface, there are four strictly conserved residues (R947, P949, K950, W1013).

Swapping $\mathrm{H}_{\mathrm{CN}}$ domains between BoNT/A and B only moderately impairs biological activity of scAABA and marginally increases biological activity of scBBAB vs. BoNT/B wild-type (Figure 3B). Accordingly, binding of scBBAB to Syt-II is unaltered, indicating a functionally folded HccB, while GT1b binding is approximately halved (Figures 4 and 7). However, the corresponding $\mathrm{H}_{C} \mathrm{AB}$ hybrid displays slightly superior binding to synaptosomes than $\mathrm{H}_{\mathrm{C}} \mathrm{B}$, which exactly reflects the biological activity of scBBAB [53]. In contrast, synaptosomal binding of $\mathrm{H}_{C} \mathrm{BA}$ is halved compared to $\mathrm{H}_{\mathrm{C}} \mathrm{A}$ [53]; as is the SV2C binding of scAABA, but its GT1b binding is maintained (Figures 5 and 7). Reduced SV2C binding of scAABA can be explained by the proximity of the SV2C binding site to the foreign $\mathrm{H}_{\mathrm{CN}} \mathrm{B}$, which might not support this interaction (Figure 1). Altogether, at least the $\mathrm{H}_{\mathrm{CN}}$ domains of serotype $\mathrm{A}$ and $\mathrm{B}$ are largely exchangeable. Whether this relies on a specific structural feature in addition to the overall lectin-like fold present in both serotypes and whether the other known BoNT serotypes also comprise this feature needs to be investigated in future studies.

In contrast to swapping $\mathrm{H}_{\mathrm{CN}} \mathrm{A}$ and $\mathrm{H}_{\mathrm{CN}} \mathrm{B}$, the substitution with $\mathrm{H}_{\mathrm{CN}} \mathrm{T}$ decreased the biological activity of scAATA 5-fold and that of scBBTB 160-fold compared to the respective BoNT wild-types (Figure $3 \mathrm{~B}$ ). The synaptosomal binding of the corresponding $\mathrm{H}_{\mathrm{C}} \mathrm{TA}$ is clearly reduced compared to $\mathrm{H}_{\mathrm{C}} \mathrm{A}$ and $\mathrm{H}_{\mathrm{C}} \mathrm{T}$ [54], but the SV2C binding of scAATA is only halved, while its GT1b binding is maintained (Figures 5 and 7), a situation already seen with scAABA. The severe reduction in potency of scBBTB 
can neither be explained by its unaltered Syt-II interaction and the $50 \%$ reduced binding to GT1b (Figures 4 and 7) nor by synaptosomal binding of the corresponding $\mathrm{H}_{\mathrm{C}} \mathrm{TB}$ hybrid, which is close to that of $\mathrm{H}_{\mathrm{C}} \mathrm{B}$ [54]. One speculation would be that scAATA and scBBTB are properly folded molecules and specifically bind to their neuronal receptors, but are then preferably sorted into neutral vesicles like TeNT, thereby failing to block acetylcholine release at the neuromuscular junction. For scAATA, this hypothesis was tested by intoxicating primary cultures of cortical neurons from the CNS [54]. However, activity of AATA was about 10-fold lower than of BoNT/A wild-type, which rejects this hypothesis. In conclusion, the $\mathrm{H}_{\mathrm{CN}}$ of BoNTs are more compatible to each other than to $\mathrm{H}_{\mathrm{CN}}$ of TeNT, probably due to their greater $\mathrm{AA}$ identity in the $\mathrm{H}_{\mathrm{CN}}$ domain as well as due to the localization of the main receptor binding sites within $\mathrm{H}_{\mathrm{CC}}$.

Additionally, the $\mathrm{H}_{\mathrm{CN}}$ domain of BoNT/A was substituted with non-clostridial polypeptides of similar size like the $26 \mathrm{kDa}$ GFP, the $21 \mathrm{kDa}$ DHFR, or the peptidic linker L12. Whereas scAAL12A behaves like the BoNT/A deletion mutant scAA-A, the substitution of the $\mathrm{H}_{\mathrm{CN}}$ domain by the rigid structure of GFP or the flexible structure of DHFR decreased biological activity of those hybrids below that of the deletion mutant scAA-A and abolished any binding to SV2C. Hence, proteins of similar size but different folding that could act as a rigid spacer do not harmonize with the surrounding translocation domain $\mathrm{H}_{\mathrm{N}}$ and the $\mathrm{H}_{\mathrm{CC}}$ domain, suggesting that $\mathrm{H}_{\mathrm{CN}}$ is more than just an extended spacer domain. The presence of $\mathrm{H}_{\mathrm{CN}}$ is vital for CNTs to exert their neurotoxicity. It might either orientate the $\mathrm{H}_{\mathrm{CC}}$ domain for proper receptor interaction or subsequent to receptor binding positions the $\mathrm{H}_{\mathrm{N}}$ domain in a $\mathrm{pH}$ dependent mechanism for membrane insertion as suggested by Montal [59]. Along that line, the helix connecting $\mathrm{H}_{\mathrm{N}}$ and $\mathrm{H}_{\mathrm{CN}}$ of BoNT/A was identified in playing an important role in $\mathrm{pH}$-dependent orientation of the $\mathrm{H}_{\mathrm{C}}$ fragment, which is important for formation of the $290 \mathrm{kDa}$ M-PTC as well as for neuronal action [60]. Besides $\mathrm{H}_{\mathrm{N}}$, the $\mathrm{H}_{\mathrm{CN}}$ mediates most of the interactions between BoNT/A and $\mathrm{E}$ and their respective non-toxic non-hemagglutinins (NTNHA) as observed in the crystal structures of the M-PTC/A and E, respectively [60,61]. For TeNT, Masuyer et al. 2017 reported a $\mathrm{pH}$-dependent movement of TeNT $\mathrm{H}_{\mathrm{C}}$, which is stabilized by novel hydrophobic interactions between a strand of $\mathrm{H}_{\mathrm{CN}}$ and a loop within $\mathrm{LC}$ further corroborating a role of $\mathrm{H}_{\mathrm{CN}}$ in domain orientation [10].

Although structurally similar, the $\mathrm{H}_{\mathrm{CN}}$ domain of TeNT cannot equally substitute those of BoNT and vice versa, leaving the possibility that $\mathrm{H}_{\mathrm{CN}} \mathrm{T}$ plays a different role in the intoxication mechanism of TeNT like the sorting for retrograde axonal transport.

\section{Conclusions}

A main function of the $\mathrm{H}_{\mathrm{CN}}$ domain besides contributing to N-glycan binding of SV2 in BoNT might be the correct positioning of the $\mathrm{H}_{\mathrm{CC}}$ domain relative to the remaining $\mathrm{LH}_{\mathrm{N}}$ of $\mathrm{BoNT}$ to provide access of the synaptic protein receptor to its binding pocket as well as to facilitate a subsequent $\mathrm{pH}$-dependent insertion of $\mathrm{H}_{\mathrm{N}}$ into the vesicle membrane. Proteins of similar size but different folding, which could act as a rigid spacer, cannot adopt that role.

\section{Materials and Methods}

\subsection{Plasmid Construction}

Expression plasmids encoding the full-length BoNT/A, BoNT/B, and TeNT (pBoNTAS, pBoNTBS, pAR1) have been described previously $[25,33]$ and were used, for example, as template DNA for amplification of gene fragments encoding $\mathrm{H}_{\mathrm{CC}}, \mathrm{H}_{\mathrm{CN}}$, and $\mathrm{H}_{\mathrm{C}}$. To easily swap the genes encoding the different $\mathrm{H}_{\mathrm{CN}}$ and $\mathrm{H}_{\mathrm{CC}}$ domains, a Nhe I site was inserted by PCR in pBoNTAS, pBoNTBS, and pAR1, causing the mutations N1093A in BoNT/A, Y1080A in BoNT/B, and I1111A/T1112S in TeNT. Analogously, a Sal I site was inserted by PCR in pBoNTAS, pBoNTBS, and pAR1 causing the mutations $\mathrm{K} 871 \mathrm{~V} / \mathrm{N} 872 \mathrm{D}$ in BoNT/A, S858V/E859D in BoNT/B, and I880D in TeNT to switch genes encoding the $\mathrm{H}_{\mathrm{CN}}$ fragments of BoNT/A, B, and TeNT or to replace $\mathrm{H}_{\mathrm{CN}} \mathrm{A}$ by GFP, DHFR, or L12 (=[Gly-Ser]6, GlyGlySerGlySerSerGlySerSerGlyGlySer) -linker, respectively. Accordingly, scAA-A lacks residues 
K871-N1093, scBB-B lacks S858-Y1080, and scTT-T lacks I880-I1111, respectively, while scAA-is devoid of residues 872-1296. In addition, the loop region connecting LC and HC of BoNT/A was substituted with a thrombin recognition sequence (LVPRGS) to allow specific activation of BoNT/A based constructs only by thrombin, as trypsin causes degradation of BoNT/A. The resulting plasmids pAtAAAS, pBBBBS, and pTTTTS (each capital letter encodes one of the following protein domain: LC, $\mathrm{H}_{\mathrm{N}}, \mathrm{H}_{\mathrm{CN}}, \mathrm{H}_{\mathrm{CC}}$, $\mathrm{t}$ encodes the thrombin site; Figure 2A) quasi encoded BoNT/A, B, and TeNT wild-type $[53,54]$. Nucleotide sequences of all newly generated constructs were verified by DNA sequencing (GATC Biotech, Konstanz, Germany).

\subsection{Expression and Purification of Recombinant Proteins}

Recombinant full-length neurotoxins were expressed under biosafety level 2 containment (project number GAA A/Z 40654/3/123) in the E. coli strain M15[pREP4] (Qiagen, Hilden, Germany), following $16 \mathrm{~h}$ of induction at $22^{\circ} \mathrm{C}$. The clear lysates obtained from $E$. coli containing the single chain neurotoxins were ultracentifuged for $30 \mathrm{~min}$ at $35,000 \times \mathrm{g}$ before purification on Streptactin-Superflow (IBA GmbH, Göttingen, Germany) according to the manufacturer's instructions and kept in $100 \mathrm{mM}$ Tris- $\mathrm{HCl}, \mathrm{pH}$ 8.0. scH6tBoNTA and $\mathrm{H}_{\mathrm{CC}} \mathrm{A}$ were purified as described earlier $[15,39]$. All recombinant proteins were shock frozen in liquid nitrogen and kept at $-70^{\circ} \mathrm{C}$. After thawing of naïve aliquots, the purified CNT was centrifuged for $10 \mathrm{~min}$ at $20,000 \times \mathrm{g}$ before use in an experiment to avoid protein aggregates. For circular dichroism (CD) analysis desired volume of protein was dialysed against PBS $\mathrm{pH} 7.4$.

GST fusion proteins (GST-rSyt-II 1-61, GST-rSV2C 454-579) were purified as described earlier $[39,43]$. GST fusion proteins eluted by glutathione were dialyzed against PBS, pH 7.4, two times with, and two times without $\beta$-mercaptoethanol.

gH6thSV2CLDSFc and gSFc were purified from cell culture supernatants of transiently transfected HEK293T cells [47]. Briefly, one day before transfection, $18 \times 10^{6}$ cells were seeded in $300 \mathrm{~cm}^{2}$ culture flasks using growth medium (DMEM (Sigma-Aldrich Chemie GmbH, Taufkirchen Germany, D5671) supplemented with 10\% FCS (PAN Biotech, P30-1502), $10 \mathrm{U} / \mathrm{mL}$ penicillin, $100 \mu \mathrm{g} / \mathrm{mL}$ streptomycin, and $2 \mathrm{mM}$ L-glutamine). Transfection was performed by exchanging the growth medium of the culture and incubating $32 \mu \mathrm{g}$ pIg+H6thSV2CLDS and $92 \mu \mathrm{L}$ branched polyethylenimine $(1 \mathrm{mg} / \mathrm{mL}$, Sigma, \#408727) in $4 \mathrm{~mL}$ DMEM without serum. Following $20 \mathrm{~min}$ of incubation at room temperature, the mixture was added to the culture. Transfection efficiency was estimated by replacing one-tenth of the amount of the DNA with the plasmid pEGFP-N2 (BD Biosciences Clontech, Stockholm, Sweden) and visual inspection of the green fluorescence of the cells one day after transfection. Following this protocol, the transfection efficiency was typically approximately $60 \%$. Cell culture supernatants were collected two, four, and six days after transfection. gH6thSV2CLDSFc was consecutively affinity purified on Talon matrix (Clontech Laboratories, Inc., Mountain View, CA, USA) and Streptactin-Superflow (IBA GmbH, Göttingen, Germany) columns according to the manufacturers' instructions and eluted using $100 \mathrm{mM}$ Tris- $\mathrm{HCl}$ (pH 8.0), $150 \mathrm{mM} \mathrm{NaCl}$ and $10 \mathrm{mM}$ Desthiobiotin.

Protein concentrations were determined subsequent to SDS-PAGE and Coomassie blue staining by using a LAS-3000 imaging system (Fuji Photo Film GmbH, Düsseldorf, Germany), the AIDA 3.51 software (Raytest, Straubenhardt, Germany), and BSA (100-1600 ng) as reference protein.

\subsection{Potency of CNT Deletion Mutants and Hybrids at MPN Hemidiaphragm Assay}

Potency of CNT deletion mutants and hybrids was determined employing the MPN assay [52,62]. In brief, the left phrenic nerve hemidiaphragm was excised from euthanized female mice of strain RjHan:NMRI (18-25 g, Janvier Labs, Genest Saint Isle, France), placed in an organ bath, and equilibrated for $15 \mathrm{~min}$ in $4 \mathrm{~mL}$ of Earle's Balanced Salt Solution, pH 7.4, gassed with $95 \% \mathrm{O}_{2}$ and $5 \% \mathrm{CO}_{2}$. The phrenic nerve was continuously electro-stimulated (frequency $1 \mathrm{~Hz}, 0.1 \mathrm{~ms}$ pulse duration, $25 \mathrm{~mA}$ current). Isometric contractions (resting tension $\sim 10 \mathrm{mN}$ ) were recorded with a force transducer (Scaime, Annemasse, France) and the software VitroDat (Föhr Medical Instruments GmbH (FMI), Seeheim, 
Germany). Toxin was applied in $4 \mathrm{~mL}$ of Earle's Balanced Salt Solution supplemented with $0.1 \%$ BSA in concentrations to allow $50 \%$ decay of the contraction amplitude within 50 to $150 \mathrm{~min}$. The times required to decrease the amplitude by $50 \%$ (paralysis time $t_{\frac{1}{2}} \leq 180 \mathrm{~min}$ ) for three CNT concentrations were used to construct the calibration curves to which a power function was fitted (y (scAAAA; $\left.30 / 100 / 270 \mathrm{pM})=710.95 \mathrm{x}^{-0.443}, R^{2}=0.9925\right)\left(\mathrm{y}(\mathrm{scBBBB} ; 90 / 270 / 890 \mathrm{pM})=798.4 \mathrm{x}^{-0.4}, R^{2}=0.8952\right)(\mathrm{y}$ (scTTTT; $\left.2.0 / 6.5 / 20 \mathrm{nM})=7586.8 \mathrm{x}^{-0.492}, R^{2}=0.9999\right)$. Each power function was used to convert the paralysis times $t_{\frac{1}{2}}$ determined for deletion mutants and hybrids into the corresponding wild-type concentrations and expressed as relative biological activity of scAAAA wild-type.

\subsection{GST-Pull-Down Assay}

The GST-pull-down assays were similarly performed as previously described [15,27].

Briefly, GST and GST fusion proteins (150 pmol each) were immobilized to $10 \mu \mathrm{L}$ glutathione-sepharose-4B matrix (Qiagen, Hilden, Germany) and subsequently incubated for $2 \mathrm{~h}$ at $4{ }^{\circ} \mathrm{C}$ with $250 \mathrm{nM} \mathrm{CNTs}$ in binding buffer (Tris- $\mathrm{HCl} \mathrm{pH} 8,150 \mathrm{mM} \mathrm{NaCl}, 0.5 \%$ Triton X-100). Beads were collected by centrifugation and washed two times each with the corresponding binding buffer. Washed pellet fractions were incubated at $37^{\circ} \mathrm{C}$ for $20 \mathrm{~min}$ in SDS sample buffer and analyzed by $10 \%$ SDS-PAGE. Protein bands were detected by Coomassie blue staining and subsequently quantified by $2 \mathrm{D}$ densitometry using the software TINA (version 2.09f, Raytest, Straubenhardt, Germany). Coomassie blue staining of BoNT/A and B vs. BSA in SDS-PAGE with subsequent densitometry was compared to A280 photometry and found very consistent results, indicating that also the BoNT hybrids used here similarly stain to each other. Unspecific binding of ligand to immobilized GST was subtracted from the BoNT specific binding signal. The value "mol\% binding" is the ratio of band intensity of the respective GST fusion protein as immobilized bait and the bound BoNT as ligand/prey corrected by the molecular weight ratio of BoNT vs. GST fusion protein.

Binding of wild-type and mutant ghSV2CLD Fc to scH6tBoNTA wild-type and the deletion mutant scAA-A, respectively, was described in [47]. Briefly, the assay was carried out in binding buffer (20 mM Tris-HCl, pH 7.4, $150 \mathrm{mM} \mathrm{NaCl}$ and $0.5 \%$ Triton X-100). A total of $10 \mu \mathrm{L}$ protein G-sepharose beads (GE Healthcare) coated with 50 pmol of ghSV2CLD Fc was incubated with 50 pmol scH6tBoNTA or scAA-A, respectively, for 2-3 h in a total volume of $200 \mu \mathrm{L}$. Following incubation, beads were collected by centrifugation at $4500 \times g$ and washed three times using binding buffer. Washed pellet fractions were incubated in sodium dodecyl sulphate (SDS) sample buffer for $5 \mathrm{~min}$ at $99^{\circ} \mathrm{C}$ and analyzed by SDS-PAGE. Proteins were visualized by means of Coomassie Blue staining.

\subsection{Liposome Binding Assay}

The Rhod-DHPE/GT1b-liposomes (41.98\% Egg-PC (8.396 $\mu \mathrm{M}), 41.98 \%$ Cholesterol $(8.396 \mu \mathrm{M})$, and $9.88 \%$ RhodamineB-DHPE $(1.976 \mu \mathrm{M}), 6.17 \%$ GT1b $(1.234 \mu \mathrm{M}))$ were kindly provided by O.G. Weingart (ETH Zurich, Switzerland) and prepared by hydration of a thin film of dried lipids. Egg-PC, cholesterol, RhodamineB-DHPE, and GT1b ganglioside receptor molecules were dissolved in chloroform and methanol (1:1) in a glass vial by gentle agitation. Subsequently, the solvent was evaporated by applying a vacuum to create a dry lipid film, which was reconstituted in $12.5 \mathrm{mM}$ HEPES pH 7.4 buffer. Shaking at $4{ }^{\circ} \mathrm{C}$ for 60 min resulted in a turbid vesicle emulsion. Following lipid film hydration, unilamellar LUV with uniform size distribution were produced by repeated extrusion of the vesicle emulsion through nucleopore track-etched polycarbonate membranes of $400 \mathrm{~nm}, 200 \mathrm{~nm}$, and finally $100 \mathrm{~nm}$ pore size, flanked by a double stack of polyethylene drain discs on each site (Whatman plc, Kent, UK) assembled in a Mini-Extruder (Avanti Polar Lipids Inc., Alabaster, AL, USA). Liposomes were stored until use in a $\mathrm{N}_{2}$ atmosphere at $4{ }^{\circ} \mathrm{C}$ in the dark. Dynamic light scattering measurement revealed a mean diameter in different liposome dilutions between 174.7 and $176.6 \mathrm{~nm}$ and a polydispersity of $0.112-0.146$.

A microtiter plate (Greiner Bio One Microplate, Fluotrac 600, high binding; black) was coated with $500 \mathrm{nM} \mathrm{CNT}$ in $100 \mu \mathrm{L}$ diluted in PBS and shaken on a plate shaker at $4{ }^{\circ} \mathrm{C}$ overnight. After two 
washing steps with $200 \mu \mathrm{L} /$ well PBS, Rhod-DHPE/GT1b-liposomes were diluted 1:500 in PBS to a concentration of $100 \mathrm{nM}$, and $100 \mu \mathrm{L}$ was added per well. The covered plate was incubated for $2 \mathrm{~h}$ at $22{ }^{\circ} \mathrm{C}$ and $300 \mathrm{rpm}$. Following two additional washing steps, $120 \mu \mathrm{L}$ of lysis buffer $(0.1 \%$ Triton X-100 diluted in $\mathrm{ddH}_{2} \mathrm{O}$ ) was added to the wells. After an incubation of $15 \mathrm{~min}$ at $22^{\circ} \mathrm{C}$ and $300 \mathrm{rpm}$, the fluorescence signal was read in a fluorescence plate reader (BioTek Synergy ${ }^{\mathrm{TM}} 4$ ) using an excitation filter of $530 \mathrm{~nm}$ and emission wavelength of $585 \mathrm{~nm}$ at $30^{\circ} \mathrm{C}$.

\subsection{Circular Dichroism Analysis}

Circular dichroism (CD) data was collected with a Jasco J-810 spectropolarimeter in a $1 \mathrm{~mm}$ path length cuvette with a concentration of $2 \mu \mathrm{M}$ respective protein in PBS pH 7.4. Spectra were recorded at $22{ }^{\circ} \mathrm{C}$ from 195 to $250 \mathrm{~nm}$ with $100 \mathrm{~nm} / \mathrm{min}$, response of $1 \mathrm{~s}$, standard sensitivity, bandwidth of $1 \mathrm{~nm}$, and five accumulations. Spectra were analyzed, processed, and visualized using Spectra Manager II software (JASCO International Co. Ltd., Tokyo, Japan). Secondary structure estimation was conducted using the SSE module of Spectra Manager II applying Yang reference.

Author Contributions: J.D., J.W., S.M. and A.R. conceived and designed the experiments. J.D., J.W. and S.M. performed the experiments and analyzed the data. A.R. wrote and revised the paper with input from all other authors. All authors have read and agreed to the published version of the manuscript.

Funding: This study was supported in part by the Bundesministerium für Bildung und Forschung (FK031L0111B) to Andreas Rummel and by the Deutsche Forschungsgemeinschaft (DFG Exzellenzinitiative GSC 108) to J.D.

Acknowledgments: We thank Nadja Krez, Tino Karnath, Pascal Werner and Beate Winter for excellent technical assistance and O.G. Weingart (ETH Zurich, Switzerland) for the gift of GT1b incorporated liposomes.

Conflicts of Interest: The authors declare no conflict of interest.

\section{Abbreviations}

The following abbreviations are used in this manuscript:

$\begin{array}{ll}\text { AA } & \text { amino acid } \\ \text { BoNT } & \text { botulinum neurotoxin } \\ \text { CD } & \text { circular dichroism } \\ \text { CNTs } & \text { clostridial neurotoxins } \\ \text { Rhod-DHPE } & \text { sulforhodamine 1,2-dihexadecanoyl-SN-glycero-3-phosphoethanolLamine, triethylammonium salt } \\ \text { Egg-PC } & \text { egg phosphatidylcholine } \\ \text { GBS } & \text { ganglioside binding site } \\ \text { GST } & \text { glutathion-S-transferase } \\ \text { h } & \text { human } \\ \text { HC } & \text { heavy chain } \\ \text { HC } & \text { carboxyl-terminal half of } \mathrm{HC} ; \mathrm{H}_{\mathrm{CN}} \mathrm{A}, \mathrm{H}_{\mathrm{CN}} \mathrm{B}, \mathrm{H}_{\mathrm{CN}} \mathrm{T}, \mathrm{H}_{\mathrm{CN}} \text { domain of BoNT serotype } \mathrm{A}, \mathrm{B}, \text { and TeNT, } \\ \mathrm{H}_{\mathrm{N}} & \text { respectively; } \mathrm{H}_{\mathrm{CN}} \text { and } \mathrm{H}_{\mathrm{CC}}: 25 \mathrm{kDa} \text { halves of } \mathrm{H}_{\mathrm{C}} \\ \mathrm{HSA} & \text { amino-terminal half of } \mathrm{HC} \\ \text { LC } & \text { human serum albumin } \\ \text { LD } & \text { light chain } \\ \text { MPN assay } & \text { luminal domain } \\ \text { MW } & \text { mice phrenic nerve hemidiaphragm assay } \\ \text { PS } & \text { molecular weight } \\ \text { S } & \text { polystyro } \\ \text { SNAP-25 } & \text { C-terminal Streptag } \\ \text { SNARE } & \text { synaptosomal associated protein of } 25 \mathrm{kDa} \\ \text { SV } & \text { soluble } N \text {-ethylmaleimide-sensitive factor attachment protein receptor } \\ \text { rSV2A-C } & \text { synaptic vesicle } \\ \text { Syt } & \text { rat synaptic vesicle glycoprotein } 2 \text { isoform } \mathrm{A}, \mathrm{B}, \text { or C } \\ \text { TMD } & \text { synaptotagmin } \\ & \text { transmembrane domain }\end{array}$




\section{References}

1. Peck, M.W.; Smith, T.J.; Anniballi, F.; Austin, J.W.; Bano, L.; Bradshaw, M.; Cuervo, P.; Cheng, L.W.; Derman, Y.; Dorner, B.G.; et al. Historical perspectives and guidelines for botulinum neurotoxin subtype nomenclature. Toxins 2017, 9, 38. [CrossRef]

2. Brunt, J.; Carter, A.T.; Stringer, S.C.; Peck, M.W. Identification of a novel botulinum neurotoxin gene cluster in enterococcus. FEBS Lett. 2018, 592, 310-317. [CrossRef] [PubMed]

3. Zhang, S.; Lebreton, F.; Mansfield, M.J.; Miyashita, S.I.; Zhang, J.; Schwartzman, J.A.; Tao, L.; Masuyer, G.; Martinez-Carranza, M.; Stenmark, P.; et al. Identification of a botulinum neurotoxin-like toxin in a commensal strain of enterococcus faecium. Cell Host Microbe 2018, 23, 169-176.e166. [CrossRef] [PubMed]

4. Zhang, S.; Masuyer, G.; Zhang, J.; Shen, Y.; Lundin, D.; Henriksson, L.; Miyashita, S.I.; Martinez-Carranza, M.; Dong, M.; Stenmark, P. Identification and characterization of a novel botulinum neurotoxin. Nat. Commun. 2017, 8, 14130. [CrossRef] [PubMed]

5. Contreras, E.; Masuyer, G.; Qureshi, N.; Chawla, S.; Dhillon, H.S.; Lee, H.L.; Chen, J.; Stenmark, P.; Gill, S.S. A neurotoxin that specifically targets anopheles mosquitoes. Nat. Commun. 2019, 10, 2869. [CrossRef] [PubMed]

6. Lamanna, C. Toxicity of bacterial exotoxins by the oral route. Science 1960, 131, 1100-1101. [CrossRef]

7. Bigalke, H. Botulinum toxin: Application, safety, and limitations. Curr. Top. Microbiol. Immunol. 2013, 364, 307-317.

8. Lacy, D.B.; Tepp, W.; Cohen, A.C.; DasGupta, B.R.; Stevens, R.C. Crystal structure of botulinum neurotoxin type A and implications for toxicity. Nat. Struct. Biol. 1998, 5, 898-902. [CrossRef]

9. Swaminathan, S.; Eswaramoorthy, S. Structural analysis of the catalytic and binding sites of clostridium botulinum neurotoxin B. Nat. Struct. Biol. 2000, 7, 693-699. [CrossRef]

10. Masuyer, G.; Conrad, J.; Stenmark, P. The structure of the tetanus toxin reveals ph-mediated domain dynamics. EMBO Rep. 2017, 18, 1306-1317. [CrossRef]

11. Kumaran, D.; Eswaramoorthy, S.; Furey, W.; Navaza, J.; Sax, M.; Swaminathan, S. Domain organization in clostridium botulinum neurotoxin type $\mathrm{E}$ is unique: Its implication in faster translocation. J. Mol. Biol. 2009, 386, 233-245. [CrossRef] [PubMed]

12. Smith, L.A. Botulism and vaccines for its prevention. Vaccine 2009, 27 (Suppl. 4), D33-D39. [CrossRef]

13. Rummel, A. The long journey of botulinum neurotoxins into the synapse. Toxicon 2015, 107, 9-24. [CrossRef] [PubMed]

14. Rummel, A. Two feet on the membrane: Uptake of clostridial neurotoxins. Curr. Top. Microbiol. Immunol. 2016, 406, 1-37.

15. Strotmeier, J.; Mahrhold, S.; Krez, N.; Janzen, C.; Lou, J.; Marks, J.D.; Binz, T.; Rummel, A. Identification of the synaptic vesicle glycoprotein 2 receptor binding site in botulinum neurotoxin A. FEBS Lett. 2014, 588, 1087-1093. [CrossRef] [PubMed]

16. Yao, G.; Zhang, S.; Mahrhold, S.; Lam, K.H.; Stern, D.; Bagramyan, K.; Perry, K.; Kalkum, M.; Rummel, A.; Dong, M.; et al. N-linked glycosylation of sv2 is required for binding and uptake of botulinum neurotoxin A. Nat. Struct. Mol. Biol. 2016, 23, 656-662. [CrossRef] [PubMed]

17. Wang, J.; Meng, J.; Nugent, M.; Tang, M.; Dolly, J.O. Neuronal entry and high neurotoxicity of botulinum neurotoxin a require its n-terminal binding sub-domain. Sci. Rep. 2017, 7, 44474. [CrossRef]

18. Bercsenyi, K.; Schmieg, N.; Bryson, J.B.; Wallace, M.; Caccin, P.; Golding, M.; Zanotti, G.; Greensmith, L.; Nischt, R.; Schiavo, G. Tetanus toxin entry. Nidogens are therapeutic targets for the prevention of tetanus. Science 2014, 346, 1118-1123. [CrossRef]

19. Fischer, A. Synchronized chaperone function of botulinum neurotoxin domains mediates light chain translocation into neurons. Curr. Top. Microbiol. Immunol. 2013, 364, 115-137.

20. Pirazzini, M.; Azarnia Tehran, D.; Zanetti, G.; Megighian, A.; Scorzeto, M.; Fillo, S.; Shone, C.C.; Binz, T.; Rossetto, O.; Lista, F.; et al. Thioredoxin and its reductase are present on synaptic vesicles, and their inhibition prevents the paralysis induced by botulinum neurotoxins. Cell Rep. 2014, 8, 1870-1878. [CrossRef]

21. Pirazzini, M.; Bordin, F.; Rossetto, O.; Shone, C.C.; Binz, T.; Montecucco, C. The thioredoxin reductase-thioredoxin system is involved in the entry of tetanus and botulinum neurotoxins in the cytosol of nerve terminals. FEBS Lett. 2013, 587, 150-155. [CrossRef] [PubMed] 
22. Blasi, J.; Chapman, E.R.; Link, E.; Binz, T.; Yamasaki, S.; De Camilli, P.; Sudhof, T.C.; Niemann, H.; Jahn, R. Botulinum neurotoxin a selectively cleaves the synaptic protein snap-25. Nature 1993, 365, 160-163. [CrossRef] [PubMed]

23. Schiavo, G.; Santucci, A.; Dasgupta, B.R.; Mehta, P.P.; Jontes, J.; Benfenati, F.; Wilson, M.C.; Montecucco, C. Botulinum neurotoxins serotypes A and E cleave snap-25 at distinct cooh-terminal peptide bonds. FEBS Lett. 1993, 335, 99-103. [CrossRef]

24. Schiavo, G.; Benfenati, F.; Poulain, B.; Rossetto, O.; Polverino de Laureto, P.; DasGupta, B.R.; Montecucco, C. Tetanus and botulinum-B neurotoxins block neurotransmitter release by proteolytic cleavage of synaptobrevin. Nature 1992, 359, 832-835. [CrossRef] [PubMed]

25. Rummel, A.; Mahrhold, S.; Bigalke, H.; Binz, T. The $\mathrm{h}_{\mathrm{cc}}$-domain of botulinum neurotoxins A and B exhibits a singular ganglioside binding site displaying serotype specific carbohydrate interaction. Mol. Microbiol. 2004, 51, 631-643. [CrossRef] [PubMed]

26. Rummel, A.; Häfner, K.; Mahrhold, S.; Darashchonak, N.; Holt, M.; Jahn, R.; Beermann, S.; Karnath, T.; Bigalke, H.; Binz, T. Botulinum neurotoxins $\mathrm{C}, \mathrm{E}$ and $\mathrm{F}$ bind gangliosides via a conserved binding site prior to stimulation-dependent uptake with botulinum neurotoxin $\mathrm{F}$ utilising the three isoforms of sv2 as second receptor. J. Neurochem. 2009, 110, 1942-1954. [CrossRef]

27. Rummel, A.; Eichner, T.; Weil, T.; Karnath, T.; Gutcaits, A.; Mahrhold, S.; Sandhoff, K.; Proia, R.L.; Acharya, K.R.; Bigalke, H.; et al. Identification of the protein receptor binding site of botulinum neurotoxins B and G proves the double-receptor concept. Proc. Natl. Acad. Sci. USA 2007, 104, 359-364. [CrossRef]

28. Stenmark, P.; Dupuy, J.; Imamura, A.; Kiso, M.; Stevens, R.C. Crystal structure of botulinum neurotoxin type A in complex with the cell surface co-receptor gt1b-insight into the toxin-neuron interaction. PLoS Pathog. 2008, 4, e1000129. [CrossRef]

29. Benson, M.A.; Fu, Z.; Kim, J.J.; Baldwin, M.R. Unique ganglioside recognition strategies for clostridial neurotoxins. J. Biol. Chem. 2011, 286, 34015-34022. [CrossRef]

30. Berntsson, R.P.; Peng, L.; Dong, M.; Stenmark, P. Structure of dual receptor binding to botulinum neurotoxin B. Nat. Commun. 2013, 4, 2058. [CrossRef]

31. Chen, C.; Baldwin, M.R.; Barbieri, J.T. Molecular basis for tetanus toxin coreceptor interactions. Biochemistry 2008, 47, 7179-7186. [CrossRef] [PubMed]

32. Fotinou, C.; Emsley, P.; Black, I.; Ando, H.; Ishida, H.; Kiso, M.; Sinha, K.A.; Fairweather, N.F.; Isaacs, N.W. The crystal structure of tetanus toxin $\mathrm{h}_{\mathrm{c}}$-fragment complexed with A synthetic gt1b analogue suggests cross-linking between ganglioside receptors and the toxin. J. Biol. Chem. 2001, 276, 32274-32281. [CrossRef] [PubMed]

33. Rummel, A.; Bade, S.; Alves, J.; Bigalke, H.; Binz, T. Two carbohydrate binding sites in the $\mathrm{h}_{\mathrm{cc}}$-domain of tetanus neurotoxin are required for toxicity. J. Mol. Biol. 2003, 326, 835-847. [CrossRef]

34. Jayaraman, S.; Eswaramoorthy, S.; Kumaran, D.; Swaminathan, S. Common binding site for disialyllactose and tri-peptide in C-fragment of tetanus neurotoxin. Proteins 2005, 61, 288-295. [CrossRef] [PubMed]

35. Nishiki, T.; Kamata, Y.; Nemoto, Y.; Omori, A.; Ito, T.; Takahashi, M.; Kozaki, S. Identification of protein receptor for clostridium botulinum type B neurotoxin in rat brain synaptosomes. J. Biol. Chem. 1994, 269, 10498-10503. [PubMed]

36. Nishiki, T.; Tokuyama, Y.; Kamata, Y.; Nemoto, Y.; Yoshida, A.; Sekiguchi, M.; Takahashi, M.; Kozaki, S. Binding of botulinum type B neurotoxin to chinese hamster ovary cells transfected with rat synaptotagmin ii cdna. Neurosci. Lett. 1996, 208, 105-108. [CrossRef]

37. Nishiki, T.; Tokuyama, Y.; Kamata, Y.; Nemoto, Y.; Yoshida, A.; Sato, K.; Sekiguchi, M.; Takahashi, M.; Kozaki, S. The high-affinity binding of clostridium botulinum type B neurotoxin to synaptotagmin ii associated with gangliosides gt1b/gd1a. FEBS Lett. 1996, 378, 253-257. [CrossRef]

38. Dong, M.; Richards, D.A.; Goodnough, M.C.; Tepp, W.H.; Johnson, E.A.; Chapman, E.R. Synaptotagmins i and ii mediate entry of botulinum neurotoxin B into cells. J. Cell Biol. 2003, 162, 1293-1303. [CrossRef]

39. Rummel, A.; Karnath, T.; Henke, T.; Bigalke, H.; Binz, T. Synaptotagmins i and ii act as nerve cell receptors for botulinum neurotoxin G. J. Biol. Chem. 2004, 279, 30865-30870. [CrossRef]

40. Strotmeier, J.; Willjes, G.; Binz, T.; Rummel, A. Human synaptotagmin-ii is not a high affinity receptor for botulinum neurotoxin B and G: Increased therapeutic dosage and immunogenicity. FEBS Lett. 2012, 586, 310-313. [CrossRef] 
41. Peng, L.; Berntsson, R.P.; Tepp, W.H.; Pitkin, R.M.; Johnson, E.A.; Stenmark, P.; Dong, M. Botulinum neurotoxin D-C uses synaptotagmin I and II as receptors, and human synaptotagmin II is not an effective receptor for type B, D-C and G toxins. J. Cell Sci. 2012, 125, 3233-3242. [CrossRef] [PubMed]

42. Dong, M.; Yeh, F.; Tepp, W.H.; Dean, C.; Johnson, E.A.; Janz, R.; Chapman, E.R. Sv2 is the protein receptor for botulinum neurotoxin A. Science 2006, 312, 592-596. [CrossRef] [PubMed]

43. Mahrhold, S.; Rummel, A.; Bigalke, H.; Davletov, B.; Binz, T. The synaptic vesicle protein $2 \mathrm{c}$ mediates the uptake of botulinum neurotoxin A into phrenic nerves. FEBS Lett. 2006, 580, 2011-2014. [CrossRef] [PubMed]

44. Dong, M.; Liu, H.; Tepp, W.H.; Johnson, E.A.; Janz, R.; Chapman, E.R. Glycosylated sv2a and sv2b mediate the entry of botulinum neurotoxin E into neurons. Mol. Biol. Cell 2008, 19, 5226-5237. [CrossRef]

45. Benoit, R.M.; Frey, D.; Hilbert, M.; Kevenaar, J.T.; Wieser, M.M.; Stirnimann, C.U.; McMillan, D.; Ceska, T.; Lebon, F.; Jaussi, R.; et al. Structural basis for recognition of synaptic vesicle protein $2 \mathrm{c}$ by botulinum neurotoxin A. Nature 2014, 505, 108-111. [CrossRef]

46. Weisemann, J.; Stern, D.; Mahrhold, S.; Dorner, B.G.; Rummel, A. Botulinum neurotoxin serotype a recognizes its protein receptor sv2 by a different mechanism than botulinum neurotoxin B synaptotagmin. Toxins 2016, 8, 154. [CrossRef]

47. Mahrhold, S.; Bergstrom, T.; Stern, D.; Dorner, B.G.; Astot, C.; Rummel, A. Only the complex n559-glycan in the synaptic vesicle glycoprotein $2 \mathrm{c}$ mediates high affinity binding to botulinum neurotoxin serotype A1. Biochem. J. 2016, 473, 2645-2654. [CrossRef]

48. Chai, Q.; Arndt, J.W.; Dong, M.; Tepp, W.H.; Johnson, E.A.; Chapman, E.R.; Stevens, R.C. Structural basis of cell surface receptor recognition by botulinum neurotoxin B. Nature 2006, 444, 1096-1100. [CrossRef]

49. Jin, R.; Rummel, A.; Binz, T.; Brunger, A.T. Botulinum neurotoxin B recognizes its protein receptor with high affinity and specificity. Nature 2006, 444, 1092-1095. [CrossRef]

50. Muraro, L.; Tosatto, S.; Motterlini, L.; Rossetto, O.; Montecucco, C. The n-terminal half of the receptor domain of botulinum neurotoxin a binds to microdomains of the plasma membrane. Biochem. Biophys. Res. Commun. 2009, 380, 76-80. [CrossRef]

51. Couesnon, A.; Pereira, Y.; Popoff, M.R. Receptor-mediated transcytosis of botulinum neurotoxin A through intestinal cell monolayers. Cell Microbiol. 2008, 10, 375-387. [CrossRef]

52. Bigalke, H.; Rummel, A. Botulinum neurotoxins: Qualitative and quantitative analysis using the mouse phrenic nerve hemidiaphragm assay (MPN). Toxins 2015, 7, 4895-4905. [CrossRef] [PubMed]

53. Rummel, A.; Mahrhold, S.; Bigalke, H.; Binz, $\mathrm{T}$. Exchange of the $\mathrm{h}_{\mathrm{cc}}$ domain mediating double receptor recognition improves the pharmacodynamic properties of botulinum neurotoxin. FEBS J. 2011, 278, 4506-4515. [CrossRef] [PubMed]

54. Holtje, M.; Schulze, S.; Strotmeier, J.; Mahrhold, S.; Richter, K.; Binz, T.; Bigalke, H.; Ahnert-Hilger, G.; Rummel, A. Exchanging the minimal cell binding fragments of tetanus neurotoxin in botulinum neurotoxin A and B impacts their toxicity at the neuromuscular junction and central neurons. Toxicon 2013, 75, 108-121. [CrossRef] [PubMed]

55. Chaddock, J.A.; Herbert, M.H.; Ling, R.J.; Alexander, F.C.; Fooks, S.J.; Revell, D.F.; Quinn, C.P.; Shone, C.C.; Foster, K.A. Expression and purification of catalytically active, non-toxic endopeptidase derivatives of clostridium botulinum toxin type A. Protein Expr. Purif. 2002, 25, 219-228. [CrossRef]

56. Montal, M. Botulinum neurotoxin: A marvel of protein design. Annu. Rev. Biochem. 2010, 79, $591-617$. [CrossRef] [PubMed]

57. Rossetto, O.; Pirazzini, M.; Montecucco, C. Botulinum neurotoxins: Genetic, structural and mechanistic insights. Nat. Rev. Microbiol. 2014, 12, 535-549. [CrossRef] [PubMed]

58. Dong, M.; Masuyer, G.; Stenmark, P. Botulinum and tetanus neurotoxins. Annu. Rev. Biochem. 2019, 88, 811-837. [CrossRef]

59. Fischer, A.; Mushrush, D.J.; Lacy, D.B.; Montal, M. Botulinum neurotoxin devoid of receptor binding domain translocates active protease. PLoS Pathog. 2008, 4, e1000245. [CrossRef]

60. Gu, S.; Rumpel, S.; Zhou, J.; Strotmeier, J.; Bigalke, H.; Perry, K.; Shoemaker, C.B.; Rummel, A.; Jin, R. Botulinum neurotoxin is shielded by ntnha in an interlocked complex. Science 2012, 335, 977-981. [CrossRef] 
61. Eswaramoorthy, S.; Sun, J.; Li, H.; Singh, B.R.; Swaminathan, S. Molecular assembly of clostridium botulinum progenitor m complex of type E. Sci. Rep. 2015, 5, 17795. [CrossRef] [PubMed]

62. Weisemann, J.; Krez, N.; Fiebig, U.; Worbs, S.; Skiba, M.; Endermann, T.; Dorner, M.; Bergström, T.; Munoz, A.; Zegers, I.; et al. Generation and characterization of six recombinant botulinum neurotoxins as reference material to serve in an international proficiency test. Toxins 2015, 7, 5035-5054. [CrossRef] [PubMed]

Publisher's Note: MDPI stays neutral with regard to jurisdictional claims in published maps and institutional affiliations.

(C) 2020 by the authors. Licensee MDPI, Basel, Switzerland. This article is an open access article distributed under the terms and conditions of the Creative Commons Attribution (CC BY) license (http://creativecommons.org/licenses/by/4.0/). 